\title{
Cost of capital and earnings transparency ${ }^{\text {is }}$
}

\author{
Mary E. Barth ${ }^{\mathrm{a}, *}$, Yaniv Konchitchki ${ }^{\mathrm{b}}$, Wayne R. Landsman ${ }^{\mathrm{c}}$ \\ a Graduate School of Business, Stanford University, Stanford, CA 94305, USA \\ ${ }^{\mathrm{b}}$ Haas School of Business, University of California at Berkeley, Berkeley, CA 94720, USA \\ ${ }^{\mathrm{c}}$ Kenan-Flagler Business School, University of North Carolina at Chapel Hill, Chapel Hill, NC 27599, USA
}

\section{A R T I C L E I N F O}

\section{Article history:}

Received 22 December 2008

Received in revised form

19 November 2012

Accepted 23 January 2013

Available online 1 February 2013

JEL classification:

D8

G12

M4

M41

Keywords:

Cost of capital

Earnings transparency

\begin{abstract}
A B S T R A C T
We provide evidence that firms with more transparent earnings enjoy a lower cost of capital. We base our earnings transparency measure on the extent to which earnings and change in earnings covary contemporaneously with returns. We find a significant negative relation between our transparency measure and subsequent excess and portfolio mean returns, and expected cost of capital, even after controlling for previously documented determinants of cost of capital.
\end{abstract}

(C) 2013 Elsevier B.V. Open access under CC BY-NC-SA license.

\section{Introduction}

This study provides evidence that firms with more transparent earnings enjoy a lower cost of capital. Firms with more transparent earnings are those whose earnings better reflect changes in the economic value of the firm. We operationalize transparency by developing a measure based on the explanatory power of the returns-earnings relation, i.e., the extent to which earnings and change in earnings covary contemporaneously with stock returns. We find that firms with more transparent earnings have a lower cost of capital as reflected in subsequent excess returns and portfolio mean subsequent returns. We also find that firms with more transparent earnings have a lower expected cost of capital. Our findings are based on tests that include controls for growth and other firm fundamentals that are known to be associated with cost of capital.

The Financial Accounting Standards Board (FASB) and the International Accounting Standards Board (IASB) state that a key purpose of financial statements is to improve decision-making by investors, lenders, and other providers of capital. To the extent that a firm's financial statements, including its earnings, are more transparent, uncertainty regarding the value of its equity may be lower, and therefore it will enjoy a lower cost of capital. Arthur Levitt, former chairman of the Securities and Exchange Commission (SEC), embraces this notion by suggesting that "high quality accounting standards ... improve liquidity [and] reduce capital costs."

\footnotetext{
We are grateful for comments from Yakov Amihud, Ryan Ball, Bill Beaver, Robert Bushman, Greg Clinch, Jennifer Conrad, S.P. Kothari (editor), Scott Joslin, Ken Peasnell, Gil Sadka, Eric So, an anonymous reviewer, and workshop participants at Louisiana State University, Tilburg University, Tsinghua University, Stanford Accounting Summer Camp, and the European Accounting Association Annual Congress. We also thank Jim Irving, Stephen Stubben, and Youfei Xiao for research assistance. We appreciate funding from the Center for Finance and Accounting Research at UNC-Chapel Hill.

* Corresponding author. Tel.: +1 650723 8536; fax: +1 6507257979.

E-mail addresses: mbarth@stanford.edu (M.E. Barth), yaniv@haas.berkeley.edu (Y. Konchitchki), wayne_landsman@unc.edu (W.R. Landsman).

${ }^{1}$ Remarks by Arthur Levitt, Inter-American Development Bank, September 29, 1997.
} 
We predict that earnings transparency is negatively associated with cost of capital. The basis for our prediction is the well-established positive relation between information asymmetry and cost of capital and our expectation that earnings transparency is negatively associated with information asymmetry. We expect a negative relation between earnings transparency and information asymmetry because when earnings transparency is low, some investors will engage in private information acquisition. Acquiring information about a firm's economic value beyond that reflected in earnings-which is low cost information about firm value-is costly. When this cost varies across investors, investors will differ in the extent to which they acquire information, which contributes to information asymmetry. Also, information asymmetry among investors can vary across firms such that it is negatively associated with transparency if investors' marginal acquisition costs are higher when there is less information about firm value beyond that reflected in earnings. However, ultimately it is an empirical question whether transparency is cross-sectionally negatively associated with information asymmetry. To the extent that earnings transparency is not negatively associated with information asymmetry, we will be unlikely to find a significant negative relation between earnings transparency and cost of capital. ${ }^{2}$

We base our measure of earnings transparency on the explanatory power of the returns-earnings relation because the relation measures the extent to which earnings captures changes in firm value. The intuition is that the higher is the explanatory power, the more earnings captures changes in firm value. Although investors can obtain information about changes in firm value from earnings or from other sources, our measure reflects only the extent to which earnings and change in earnings, and information correlated with earnings and change in earnings, explain returns.

Because both earnings transparency and cost of capital can differ across firms and vary over time, we base our earnings transparency measure on only current information and design the measure to permit cross-sectional and intertemporal variation. We permit intertemporal variation in our measure by estimating annual returns-earnings relations because there are several sources of intertemporal variation in earnings transparency that we expect to lead to economically meaningful variation in the cost of capital. One source is changes in accounting standards. We permit cross-sectional variation by exploiting industry and industry-neutral commonalities among firms in the returns-earnings relation, where industry-neutral commonalities are commonalities unrelated to the firm's primary industry. To exploit industry commonalities, we estimate annual returns-earnings relations by industry. To exploit industry-neutral commonalities, we estimate annual returns-earnings relations by quartile portfolios based on the residuals from the industry estimations. These portfolio estimations capture cross-sectional differences in the returns-earnings relation that are not captured fully by industry estimation. The portfolios are industry-neutral because each portfolio has the same industry composition. Our earnings transparency measure for each firm-year is the sum of the explanatory powers from that firm-year's returnsearnings industry and industry-neutral relations.

Application of accounting standards can result in variation in the explanatory power of the returns-earnings relation reflecting variation in earnings transparency as well as variation in firm fundamentals known to be related to cost of capital. For example, earnings captures poorly changes in firm value for growth firms because changes in internally generated intangible assets and growth options are not recognized in earnings. As a result, earnings of high growth firms are not transparent and high growth firms will have low explanatory power in the returns-earnings relation. However, growth is known to be associated with cost of capital regardless of whether earnings of high growth firms lack transparency. As a result, variation in our earnings transparency measure is likely correlated with intertemporal changes and cross-sectional differences in firm fundamentals such as growth. Therefore, detecting a relation between our earnings transparency measure and cost of capital could be attributable to earnings transparency or such firm fundamentals. To address this possibility, our tests include controls for growth and other firm fundamentals that are known to be associated with cost of capital.

If greater earnings transparency is associated with lower cost of capital, we should observe a negative relation between our earnings transparency measure and subsequent returns. We test whether this is the case using two approaches. The first tests for a relation between earnings transparency and subsequent excess returns, and the second tests for a relation between earnings transparency and portfolio mean subsequent returns. In our excess returns tests, we estimate crosssectional relations between our earnings transparency measure and firms' subsequent returns in excess of returns predicted based on the Fama-French and momentum factors, which reflect known determinants of cost of capital. In our portfolio mean returns tests, we sort firms into portfolios based on our earnings transparency measure and test whether, after controlling for the Fama-French and momentum factors, mean returns are lower for higher transparency portfolios. If greater earnings transparency is associated with lower cost of capital, we also should observe a negative relation between our earnings transparency measure and a proxy for expected cost of capital. To test this, we estimate cross-sectional relations between our measure of earnings transparency and a proxy for expected cost of capital based on the Fama-French and momentum factors. We conduct our tests using a large sample of US firms over a 27-year period.

We find that our earnings transparency measure is significantly negatively related to subsequent excess and portfolio mean returns, which indicates that earnings transparency explains subsequent returns incremental to the Fama-French and momentum factors. We also find that our earnings transparency measure is significantly negatively related to our proxy for expected cost of capital, which indicates that earnings transparency and the combination of the Fama-French and

\footnotetext{
${ }^{2}$ Section 5 provides evidence that our earnings transparency measure is negatively associated with measures of information asymmetry used in prior research, which is consistent with the transparency measure reflecting intertemporal and cross-sectional variation in information asymmetry.
} 
momentum factors reflect common information. However, the expected cost of capital finding obtains regardless of whether the fundamental risk characteristics underlying the factors are included in the estimating equation. This finding indicates that earnings transparency reflects information associated with expected cost of capital incremental to that reflected in these characteristics. Findings from all tests are robust to inclusion of explicit controls for leverage, growth, and the magnitude of the earnings response coefficient in the returns-earnings relation. In addition, findings relating to subsequent excess and portfolio mean returns are robust to inclusion of controls for changes in cash flow and cash flow risk, and findings relating to expected cost of capital are robust to using a measure of expected cost of capital implied by analysts' earnings forecasts. Collectively, these findings are consistent with greater earnings transparency being associated with lower cost of capital.

Using a relevance measure bearing some resemblance to our earnings transparency measure, Francis et al. (2004) reports evidence of negative relations between its measure and subsequent returns and a proxy for expected cost of capital. Although Francis et al. (2004) and we have similar predictions regarding the negative association between relevance/earnings transparency and cost of capital, the tests in Francis et al. (2004) do not support that study's inferences. The reported $t$-statistics in Francis et al. (2004) are biased upwards because the statistics do not take into account correlation of regression residuals. We show that after taking into account such correlation, there is no significant relation between the Francis et al. (2004) measure and cost of capital. A key distinction between our study and Francis et al. (2004) is that we develop an earnings transparency measure that is based only on current information, which likely accounts for our ability to find a significant relation between earnings transparency and cost of capital.

The remainder of this paper is organized as follows. Section 2 discusses the basis of our prediction and related research. Section 3 explains why earnings transparency varies across firms and over time. Section 4 develops the research design, Section 5 describes the sample, and Section 6 presents our results. Section 7 concludes the study.

\section{Basis for prediction and related research}

We predict that earnings transparency is negatively associated with cost of capital. There is an extensive literature showing that information asymmetry is positively associated with cost of capital (e.g., Diamond and Verrecchia, 1991). Therefore, earnings transparency will be negatively associated with cost of capital if transparency is negatively associated with information asymmetry. We expect that earnings transparency is negatively associated with information asymmetry based on the following reasoning.

When earnings transparency is low, earnings — which is informative and available at little or no cost - does not capture to a large extent changes in a firm's economic value. This will lead some investors to engage in private information acquisition. Acquiring information about a firm's economic value beyond that reflected in earnings is costly. It is likely that investors will differ in the extent to which they acquire information when there are differences in their marginal acquisition costs, which contributes to information asymmetry. ${ }^{3}$ In addition, information asymmetry among investors can vary across firms such that it is negatively associated with transparency if investors' marginal acquisition costs are higher when there is less information about firm value beyond that reflected in earnings. To the extent that information asymmetry is not negatively associated with earnings transparency, we will be unlikely to find a significant negative relation between earnings transparency and cost of capital. Section 5 reports empirical evidence that our transparency measure is negatively associated with measures of information asymmetry used in prior research, which is consistent with earnings transparency and information asymmetry being negatively related.

Although there is an extensive empirical literature linking various characteristics of accounting information to proxies for equity cost of capital, with one exception, no study tests directly for a link between earnings transparency and cost of capital. Accounting characteristics these studies examine include proxies for voluntary disclosure levels (Welker, 1995; Botosan, 1997; Healy et al., 1999; Lang and Lundholm, 2000; Botosan and Plumlee, 2002), accruals quality (Francis et al., 2005; Ecker et al., 2006), and various accounting-based and/or market-based measures of accounting quality (Bhattacharya et al., 2003; Francis et al., 2004). Other studies provide empirical support for a link between quality of accounting information and proxies for cost of debt capital (Sengupta, 1998; Beatty et al., 2002; Francis et al., 2005). ${ }^{4}$

Only Francis et al. (2004) examines the relation between cost of capital and a measure that bears some resemblance to our earnings transparency measure. The measure is the adjusted $R^{2}$ from a regression of returns on earnings and change in earnings, which that study notes is adapted from the measure in an earlier version of our study. ${ }^{5}$ Francis et al. (2004) refers to this measure as relevance, estimates it based on firm-by-firm time-series regressions using ten-year rolling windows of

\footnotetext{
${ }^{3}$ If information about firm value other than that reflected in earnings is available at little or no cost, it is possible that information asymmetry is low regardless of the level of earnings transparency. If this is the case, there will be no relation between earnings transparency and cost of capital.

${ }^{4}$ Although earnings quality and earnings transparency are likely related, firms with identical earnings quality can have different earnings transparency. For example, consider two hypothetical software firms, MegaSoft and TinySoft, each of which has proportionately similar revenues, expenses, and research and development costs, and each accounts for these items using US GAAP. Thus, the mapping from earnings to cash flows is the same for both firms and therefore the firms have the same earnings quality. Suppose information about MegaSoft's earnings is adequate for investors to have a clear understanding of valuation implications of earnings, but information about TinySoft's earnings is not. That is, even though the mapping from earnings to cash flows is the same for both firms, the explanatory power between earnings and return is likely to be higher for MegaSoft.

${ }^{5}$ Francis et al. (2004) defines transparency/relevance as the negative of adjusted $R^{2}$. This sign convention is opposite to ours. We apply our sign convention when discussing that study's findings.
} 
fifteen-month returns, and uses it and a factor return constructed from it to test for an association between relevance and cost of capital using subsequent excess returns and a proxy for expected cost of capital. The study reports that the relevance factor is significantly negatively associated with subsequent returns and expected cost of capital. However, Francis et al. (2004) bases its inferences on test statistics that do not take account of correlation of regression residuals. ${ }^{6}$

\section{Variation in earnings transparency}

Cost of capital can vary cross-sectionally and intertemporally (e.g., Fama and French, 1992, 1993; Campbell et al., 2001; $\mathrm{Xu}$ and Malkiel, 2003). Variation in cost of capital can reflect differences in risk, including the risk arising from information asymmetry associated with earnings transparency, which also can vary cross-sectionally and intertemporally. Only if variation in earnings transparency reflects variation in information asymmetry will variation in earnings transparency explain variation in cost of capital incremental to other known determinants of cost of capital.

There are several sources of cross-sectional variation in earnings transparency. First, earnings is not designed to reflect all changes in economic value. For example, the accounting system is not designed to capture economic benefits associated with expected future contracts from current customer relationships. Second, the accounting system does not uniformly measure earnings in a manner that reflects changes in economic value. ${ }^{7}$ Third, the way in which earnings maps into firm value can differ across firms for a variety of reasons that are not necessarily directly related to accounting. ${ }^{8}$ Fourth, because of differences in incentives managers face, firms differ in the amount of discretion their managers apply opportunistically.

Similarly, there are several sources of intertemporal variation in earnings transparency, which we expect to lead to economically meaningful variation in the cost of capital. One source is changes in accounting standards. For example, Statement of Financial Accounting Standards No. 133 (SFAS 133, Financial Accounting Standards Board (FASB), 1998) requires recognition of derivative financial instruments that affects earnings, but recognition of these instruments was not required prior to SFAS 133 . A second source is changes in the mix of a firm's assets. For example, until recently many insurance companies' assets and liabilities related only to insurance policies, but recently these companies have also invested in credit default swaps. As a result, insurance companies' asset mix changed and so likely did their earnings transparency. A third source is that, because of these changes or other reasons, e.g., changes in the clarity of firms' disclosures, the mapping of earnings into firm value can differ over time. Because there is cross-sectional variation in transparency, the effects of these intertemporal changes are likely to affect different firms differently. ${ }^{9}$

Because our sample comprises US firms, cross-sectional and intertemporal variations in transparency reflect effects of exposure to the US financial reporting system, which includes US GAAP, SEC regulation, and the US legal system. When a firm commits to the US financial reporting system, it commits to US reporting practices and changing practices when that system changes or when the way in which the system applies to the firm changes, e.g., when its asset mix changes. All aspects of the financial reporting system evolve and affect firms differently, thereby contributing to intertemporal and cross-sectional variation in earnings transparency. ${ }^{10}$

\section{Research design}

\subsection{Earnings transparency measure}

We operationalize earnings transparency by developing a measure based on the explanatory power of the returnsearnings relation, i.e., the extent to which earnings and change in earnings covary contemporaneously with stock returns. Regardless of the source of variation in earnings transparency, higher (lower) transparency will result in higher (lower) explanatory power in the returns-earnings relation. Although investors can obtain information about changes in firm value from earnings or from other sources, our measure reflects only the extent to which earnings and change in earnings, and information correlated with earnings and change in earnings, explain returns.

\footnotetext{
${ }^{6}$ Section 6.3 discusses tests using the Francis et al. (2004) relevance measure that take into account residual correlation. Findings reveal the Francis et al. (2004) relevance measure is not significantly related to cost of capital.

7 Consider examples relating to fair value, pension, and oil and gas accounting. Firms with more assets measured at fair value could have higher explanatory power in their contemporaneous returns-earnings relations than those with more assets measured at modified historical cost. The effects of pension plan disclosures on transparency are likely to vary depending on whether a firm has defined benefit pension plans. Similarly, the effects of oil and gas disclosures on transparency are relevant only to firms with oil and gas activities.

${ }^{8}$ For example, firms may differ in the extent to which they convey information using conference calls or are covered by analysts.

${ }^{9}$ Consider the example of SFAS 133, which requires derivatives to be recognized at fair value, with changes in fair value recognized in income or other comprehensive income, and enhances derivatives disclosures. Application of SFAS 133 likely clarifies the valuation implications of bank earnings, but not necessarily those of retail firms that have few derivatives. Thus, it is possible a retail firm and a bank can have different earnings transparency in one year, e.g., before application of SFAS 133, but similar transparency in the next year, e.g., after application of SFAS 133.

${ }^{10}$ Based on Kyle (1985) and Diamond and Verrecchia (1991), Leuz and Verrecchia (2000) predicts that the relation between liquidity-a cost of capital proxy - and disclosure should be stronger when a firm credibly commits to higher financial reporting quality. Empirical studies testing this prediction typically focus on a firm's commitment to apply a set of accounting standards or a firm's decision to cross-list its shares on a foreign stock exchange (Leuz and Verrecchia, 2000; Leuz, 2003; Daske et al., 2008). We do not focus on cost of capital effects associated with a commitment to reporting quality because all sample firms are committed to the US financial reporting system, including application of US GAAP.
} 
To construct our earnings transparency measure, TRANS, we use adjusted $R^{2} \mathrm{~s}$ from annual cross-sectional regressions based on the relation between earnings and change in earnings deflated by price, $E / P$ and $\Delta E / P$, and contemporaneous annual stock returns (Easton and Harris, 1991; Bushman et al., 2004). Appendix A, Section A.1, provides the details. We interpret higher explanatory power in these returns-earnings regressions as indicating greater earnings transparency. Valuation research establishes a link between equity book value and earnings and stock prices (Ohlson, 1995); earnings and change in earnings are the amounts corresponding to equity book value and earnings when explaining stock returns rather than stock prices.

We construct TRANS using a two-step estimation procedure designed to permit intertemporal and cross-sectional variation in our earnings transparency measure. Our measure for each firm-year is the sum of the explanatory powers from that firm-year's returns-earnings relations estimated in the two steps. ${ }^{11}$ The first $R^{2}$ we use to construct TRANS is that from annual returns-earnings relations estimated by industry. By construction, this component of TRANS is the same for all firms for a given industry-year. There is a strong industry component to the returns-earnings relation as a result of accounting practices likely being similar within industries (Barth et al., 1999, 2005). However, estimating the returnsearnings relation by industry is not likely to capture fully differences across firms in the returns-earnings relation (Barth et al., 2005). First, some accounting practices that affect the returns-earnings relation apply to firms in all industries. Second, earnings can differ in the extent to which it reflects management's information and thus changes in the economic value of the firm. Third, identifying a firm's industry is difficult. Not only is the concept of industry not precisely defined, but also many firms operate in multiple industries.

The second $R^{2}$ we use to construct TRANS is that from the annual returns-earnings relation estimated by portfolio, where portfolio membership is based on the residuals from the industry regressions. As explained in Appendix A, there are four portfolios for each year, where, for example, the first portfolio is comprised of the quartile of observations from each annual industry regression with the most negative residuals. Thus, the portfolio regressions capture cross-sectional differences in the returns-earnings relation that are not captured fully by industry estimation. Also, the portfolios are industry-neutral because each portfolio has the same industry composition. Thus, differences in the $R^{2} \mathrm{~s}$ from the portfolio regressions cannot be attributed to differences in industry membership. This approach is analogous to that used in Rouwenhorst (1998) in developing size- and country-neutral relative return portfolios.

If our grouping of firms into portfolios fails to reflect commonality in the returns-earnings relation among the firms within each portfolio, then the $R^{2} \mathrm{~s}$ will be small. However, evidence in Table 2, Panel B, reveals substantial commonality among firms in each portfolio. In particular, the mean $R^{2}$ s range from $17 \%$ to $42 \%$, with a mean of $32 \%$. All are substantially larger than untabulated mean $R^{2} \mathrm{~s}$ from year-by-year regressions, $10 \%$, and industry-by-industry regressions, $13 \%$. The $R^{2} \mathrm{~s}$ from our portfolio regressions are substantially higher than those reported in prior research (e.g., Lev, 1989$){ }^{12}$

Our earnings transparency measure for firm $i$ in year $t, T R A N S_{i, t}$, is the sum of the $R^{2}$ s pertaining to firm $i$ 's industry and industry-neutral returns-earnings regressions in year $t$, which we label TRANSI and TRANSIN. Thus,

$$
\operatorname{TRANS}_{i, t} \equiv \operatorname{TRANSI}_{j, t}+\operatorname{TRANSIN}_{p, t},
$$

where $j$ and $p$ denote industry and portfolio.

If cross-sectional and intertemporal variation in TRANS is not reflective of variation in earnings transparency, e.g., if TRANS exhibits greater variation than earnings transparency, then basing our tests on TRANS will bias against detecting a relation between earnings transparency and cost of capital. Basing our tests on TRANS will bias in favor of detecting a relation between earnings transparency and cost of capital_even if none exists_if TRANS is correlated with other firm fundamentals that determine cost of capital, such as growth. For example, earnings captures poorly changes in firm value for growth firms because changes in internally generated intangible assets and growth options are not recognized in earnings. As a result, earnings of high growth firms are not transparent and high growth firms will have low TRANS. However, growth is known to be associated with cost of capital regardless of whether earnings of high growth firms lack transparency. As a result, detecting a relation between TRANS and cost of capital could be attributable to earnings transparency or growth because variation in TRANS is likely correlated with intertemporal changes and cross-sectional differences in growth. Thus, as explained in Section 4.2, our tests relating TRANS to cost of capital include controls for known risk factors, i.e., the Fama-French and momentum factors, that likely are associated with these firm fundamentals. In addition, Section 6.4 reports that our inferences are unaffected by inclusion of an explicit control for growth.

\footnotetext{
${ }^{11}$ Ideally, we would like to construct a firm- and year-specific measure of earnings transparency. To construct a firm-specific measure, one could estimate a time-series regression for each firm. However, such an approach does not permit intertemporal variation in earnings transparency. To construct a year-specific measure, one could estimate a separate cross-sectional regression for each year. However, such an approach does not permit cross-sectional variation in earnings transparency. To obtain an estimate of a firm's earnings transparency, it is necessary to group firm-year observations in some way. We use annual cross-sectional estimation and our grouping procedures to permit cross-sectional and intertemporal variation in earnings transparency within the constraints imposed by empirical estimation.

${ }^{12}$ Forming portfolios based on residuals from the industry regressions does not effectively group firms ex ante according to the magnitude of their returns. First, although for our sample the untabulated cross-industry mean correlation between returns and residuals from the annual industry returnsearnings regressions is $92 \%$, the untabulated mean cross-portfolio correlation from the annual portfolio regressions is only $54 \%$. Second, untabulated findings from regressions based on portfolios explicitly ranked on returns reveal little explanatory power; the mean (across 27 years) adjusted $R^{2}$ is only $4 \%$. However, consistent with our predictions, grouping firms based on industry residuals groups firms with common risk characteristics as indicated by untabulated mean ex post annual raw returns that increase monotonically across portfolios.
} 


\subsection{Earnings transparency, subsequent excess returns, and portfolio mean returns}

We test for a relation between TRANS and cost of capital using excess and portfolio mean subsequent returns. Such tests are commonly employed in the finance literature to determine whether posited risk factors are associated with cost of capital by determining whether such factors explain subsequent returns incremental to the Fama-French and momentum factors (e.g., Fama and French, 1993; Mohanram and Rajgopal, 2009; Konchitchki, 2011). The motivation for these tests is that firm risk is more complex than is captured by the projection of returns on the Fama-French and momentum factor returns. Evidence that a posited risk factor incrementally explains subsequent returns is viewed as evidence consistent with the risk factor reflecting dimensions of cost of capital not captured by the Fama-French and momentum factors.

To test for a relation between earnings transparency and subsequent excess returns, we regress on TRANS the firm's subsequent return in excess of the firm's predicted return based on the Fama-French and momentum factors. In particular, we estimate the following equation:

$$
\text { FFRET }_{i, t+1}=\gamma_{0}+\gamma_{1} \operatorname{TRANS}_{i, t}+\gamma_{2} \text { DBTA }_{i, t+1}+\eta_{i, t+1},
$$

where the subscripts $i$ and $t$ denote firm and year.

The dependent variable, FFRET, is an annualized excess return computed using compounded monthly returns. In particular, FFRET for month $m$ is the firm's realized month $m$ return in excess of the risk-free rate minus the firm's predicted return based on the Fama-French and momentum factor betas estimated using Eq. (A5) in Appendix A, each multiplied by the month $m$ realized factor returns. Thus, FFRET is the firm's realized return minus its expected return, conditional on the realized factor returns, assuming the firm's factor betas do not change during year $t+1$. To mitigate the effects of error in estimating the betas, we treat as missing observations for which FFRET or the monthly compounded riskfree rate adjusted annual return minus the predicted monthly compounded annual return from Eq. (A5) is less than $-1 .{ }^{13}$ If greater earnings transparency is associated with lower cost of capital, we should observe a negative relation between TRANS and subsequent excess returns. Thus, we predict $\gamma_{1}$ is negative. ${ }^{14}$

We include DBTA, the ratio of long-term debt to total assets, in Eq. (2) to avoid bias in the coefficient on TRANS resulting from omission of DBTA if leverage is related to cost of capital. However, we make no prediction for the sign of its coefficient, $\gamma_{2} \cdot{ }^{15}$ We estimate Eq. (2) pooling observations cross-sectionally and over time, and by year. For the pooled regression, we base tests statistics on residuals clustered by firm and including year fixed effects (Petersen, 2009). For the by-year regressions, following Fama and MacBeth (1973), we base test statistics on the mean and standard deviation of the coefficients. ${ }^{16}$

To test for a relation between earnings transparency and portfolio mean returns, we first sort firms into one of ten portfolios based on TRANS in month $m-1$. Firms with the highest (lowest) TRANS are placed into portfolio ten (one). Then, we estimate a regression, by portfolio, i.e., $p=1, \ldots, 10$, of the value-weighted month $m$ portfolio return, $R_{p, m}$, on the month $m$ Fama-French and momentum factors: ${ }^{17}$

$$
R_{p, m}-R_{f, m}=\alpha_{p}+\beta_{R M R F, p}\left(R_{M, m}-R_{f, m}\right)+\beta_{S M B, p} S M B_{m}+\beta_{H M L, p} H M L_{m}+\beta_{M O M, p} M O M_{m}+\varepsilon_{p, m} .
$$

$\alpha_{p}$ is portfolio $p$ 's mean realized return in excess of the risk-free rate conditional on the realized factor returns, permitting portfolio $p$ 's factor betas to be estimated contemporaneously with $\alpha_{p}$. If greater earnings transparency is associated with lower cost of capital incremental to the Fama-French and momentum factors, we should observe a negative relation between TRANS and the portfolio alphas (Fama and French, 1993). Thus, we predict $\alpha_{10}$ is less than $\alpha_{1}$. Because the residuals likely are correlated across the ten portfolio regressions, we estimate the portfolio regressions using seemingly unrelated regression (Zellner, 1962) ${ }^{18}$ An advantage of conducting portfolio mean returns tests is that the estimation procedure permits factor betas, i.e., risk, to be estimated contemporaneously with returns.

By design, the factor betas in the portfolio mean returns tests reflect average risk over the estimation period. That is, the sensitivity of portfolio mean returns for each of the ten TRANS-based portfolios is assumed to be the same over the estimation period. This assumption differs from that associated with the excess returns tests, in which factor betas for each firm are estimated over a shorter period-60 months-but are predetermined when estimating excess returns. Because the tests rest on different assumptions regarding factor betas, finding consistent results for both tests

\footnotetext{
13 These restrictions eliminate from the sample 323 firm-year observations.

14 Although use of subsequent excess returns to test for associations with cost of capital is common in empirical finance (e.g., Fama and French, 1997), doing so requires several assumptions, including rational expectations and stationarity of factor betas. If betas are not stationary, subsequent excess returns can differ from zero because of changes in factor betas. As in prior research, we assume that any such changes only add noise to our tests. Subsequent excess returns also can differ from zero because of new information and, thus, such tests can lack power and be biased if the new information is correlated with TRANS. In Section 6.4, we report results from specifications of Eq. (2) that include controls for new information.

${ }^{15}$ We also estimated Eq. (2) omitting DBTA. Inferences relating to TRANS are unaffected.

16 The Fama-MacBeth procedure is unaffected by cross-sectional correlation of residuals. Following Fama and French (1998), we do not attempt to adjust the by-year estimations for correlation of residuals across years because it is unlikely that excess returns, and thus residuals, are serially correlated.

17 Untabulated findings relating to equal-weighted portfolio returns result in similar inferences.

18 Although any remaining correlation between residuals for portfolios 1 and 10 could affect inferences from the test of whether $\alpha_{10}$ is less than $\alpha_{1}$, untabulated Pearson and Spearman correlations are insignificant.
} 
makes it less likely that our inferences are affected by changes in risk associated with the Fama-French and momentum factors.

To provide additional insights into the relation between earnings transparency and cost of capital, we also test whether the betas estimated using Eq. (3) vary systematically across the TRANS portfolios. Determining whether and which betas vary systematically reveals the factors with which TRANS is correlated. However, regardless of the pattern of the betas, finding that the portfolio alphas vary across TRANS portfolios indicates that earnings transparency reflects dimensions of cost of capital that the Fama-French and momentum factors do not.

\subsection{Earnings transparency and expected cost of capital}

We next test whether TRANS is negatively related to an estimate of expected cost of capital based on the Fama-French and momentum four-factor model. Finding such a relation indicates that earnings transparency and a combination of the factors reflect common information. The Fama-French model is an empirical factor-generating model and does not identify explicitly which economic risks underlie the factors. Several studies attempt to identify these risks (e.g., Lettau and Ludvigson, 2001; Petkova, 2006). Although these studies show that the factor returns appear to reflect empirically dimensions of risk identified by asset pricing models, it remains an open question what dimensions of risk the factors represent. Thus, it is possible that the factor returns reflect risk arising from information asymmetry (Hughes et al., 2007; Lambert et al., 2007).

We test whether greater earnings transparency is associated with lower expected cost of capital by estimating the following equation:

$$
E C C_{i, t}=\gamma_{0}+\gamma_{1} \operatorname{TRANS}_{i, t}+\gamma_{2} \text { DBTA }_{i, t}+\gamma_{3} \text { MVE }_{i, t}+\gamma_{4} \text { BM }_{i, t}+\gamma_{5} \text { Beta }_{i, t}+\gamma_{6} \text { FFMom }_{i, t}+\eta_{i, t},
$$

where $E C C_{i, t}$ is firm $i$ 's expected cost of capital for year $t+1$, based on information available as of the end of year $t .^{19}$ If greater earnings transparency is associated with lower expected cost of capital as measured by the four-factor model, we should observe a negative relation between TRANS and ECC. Thus, we predict $\gamma_{1}$ is negative.

As Section A.2 of Appendix A explains, to obtain an estimate of expected cost of capital, we use the four-factor model, with time-varying factor loadings, risk-free rates, and risk premia (Ang and Liu, 2004; Ibbotson Associates, 2005; Massa et al., 2005). As with Eq. (2), we include DBTA in Eq. (4) to avoid bias in the coefficient on TRANS that could result from omission of DBTA. ${ }^{20}$

To provide evidence on the extent to which any correlation between TRANS and ECC is attributable to fundamental risk characteristics identified in prior research, we estimate two versions of Eq. (4), one that excludes these characteristics, and one that includes them. The fundamental characteristics are $M V E$, the natural logarithm of market value of equity; BM, the equity book-to-market ratio; Beta, the CAPM beta; and FFMom, return momentum as implemented on the Fama and French website, i.e., return over the ten months that end two months prior to fiscal year-end. Based on prior research, we predict $\gamma_{3}$ and $\gamma_{4}$ are negative, and $\gamma_{5}$ and $\gamma_{6}$ are positive.

As with Eq. (2), we estimate Eq. (4) pooling observations cross-sectionally and over time, and by year. For the pooled regression, we base tests statistics on residuals clustered by firm and year (Gow et al., 2010). For the by-year regressions, we base test statistics on the mean and standard deviation of the coefficients obtained from estimation of a seemingly unrelated regression system of equations. We specify Eq. (4) with expected cost of capital as a function of earnings transparency, and not vice versa. This is because although expected cost of capital can affect a firm's future financial statement policy decisions and hence future earnings transparency, TRANS cannot be a function of expected cost of capital because a firm's current earnings transparency, TRANS, is known at the time investors assess the expected risk premium for its stock.

Finding a negative relation between TRANS and ECC is evidence that TRANS captures dimensions of risk reflected in the Fama-French and momentum factors. If so, $\gamma_{1}$ will be negative. If not, $\gamma_{1}$ will be insignificantly different from zero.

\section{Sample and descriptive statistics}

Our tests are based on a sample of US firms and 27 sample years, 1974-2000. Because construction of TRANS requires earnings lagged one year and FFRET and ECC require return data for 60 prior months, we use some data for years preceding 1974. To facilitate comparison of results, we restrict the sample period to be the same for all of our analyses. The final sample comprises 51,612 firm-year observations for 6,237 firms and reflects the data requirements described below.

To construct TRANS using Eqs. (A2) and (A3) in Appendix A, Section A.1, we obtain data from the CRSP Monthly Stock File and the Compustat Industrial Annual databases. To mitigate the effects of outliers, following Easton and Harris (1991) we treat as missing observations for which any of the earnings variables, $E_{t} / P_{t-1}, E_{t-1} / P_{t-1}$, or $\Delta E_{t} / P_{t-1}$, is not between +1.5 and -1.5 . We also treat as missing observations for which annual return, $R E T$, is in the extreme top and bottom one percentile (Kothari and Zimmerman, 1995; Collins et al., 1997; Fama and French, 1998; Barth et al., 1999), and observations with negative equity book value to avoid the ratio of long-term debt to total assets from exceeding 1 . We also

\footnotetext{
${ }^{19}$ For expositional convenience, we use the same notation for coefficients and error terms in Eqs. (2) and (4). In all likelihood they differ.

${ }^{20}$ We also estimated Eq. (4) omitting DBTA. Inferences relating to TRANS are unaffected.
} 
restrict the sample to observations with total assets and total revenue in excess of $\$ 10$ million, and share price in excess of $\$ 1$. We use the industry classifications in Barth et al. (1998). If the industry component of TRANS, TRANSI, is negative in year $t$, we set it to zero because negative explanatory power is not economically meaningful. To construct FFRET and ECC, we obtain monthly returns from CRSP and the factor returns from the Fama-French database. We winsorize ECC to be between 0.0 and 0.5 because it is unlikely that any firm has a negative expected cost of capital or one in excess of $50 \%{ }^{21} D B T A$ is constructed using data from the Compustat Industrial Annual database.

Table 1 presents descriptive statistics for the variables used in our estimating equations. Panel A presents overall distributional statistics combining all industries and years, Panel B presents distributional statistics for each industry, and Panel C presents Pearson and Spearman correlations. Panel A reveals TRANS averages $42 \%$ and ranges from 3\% to $143 \%$. The industry statistics in Panel B indicate that this variation is attributable to both industry and industry-neutral differences. For example, mean TRANSI (excluding Other) ranges from 9\% for computers, insurance and real estate, pharmaceuticals, services, and transportation to $17 \%$ for food. Panel A also indicates that expected cost of capital, ECC, also varies considerably, with a mean of 0.16 and a standard deviation of 0.12 .

Panels A and B indicate that the industry component of TRANS, TRANSI, is, on average, substantially smaller than the industry-neutral component, TRANSIN. For the full sample, mean TRANSI is $11 \%$, which is higher than the untabulated mean of $10 \%$ from annual regressions pooling observations without partitioning by industry. Strikingly, mean TRANSIN is $31 \%$, which indicates that partitioning firm-year observations by the extent to which the industry specification fails to explain returns substantially improves the explanatory power of earnings and change in earnings. The means of both TRANSI and TRANSIN are representative for firms in all 15 industries.

Table 1, Panel C, indicates that FFRET is significantly negatively correlated with TRANS based on the Pearson but not the Spearman correlation. ${ }^{22}$ Similarly, the components of TRANS, TRANSI and TRANSIN, are significantly negatively correlated with FFRET based on the Pearson but not the Spearman correlation. ECC is significantly negatively correlated with TRANS and with each of its components. However, we test our predictions using the multivariate regression Eqs. (2), (3), and (4). Table 1, Panel C, also indicates that ECC and FFRET are negatively correlated. ECC and FFRET need not be positively correlated because ECC reflects dimensions of cost of capital captured by the Fama-French and momentum factors, and FFRET reflects dimensions of cost of capital not captured by these factors. ${ }^{23}$ Panel $C$ also indicates that DBTA is positively correlated with ECC and negatively correlated with FFRET. These correlations are consistent with ECC, but not FFRET, reflecting financial risk as reflected in DBTA.

As an external validity check on TRANS as a proxy for earnings transparency, we calculate correlations between it and five disclosure/transparency measures used in prior research. These are AIMR disclosure indices (e.g., Botosan, 1997) and four S\&P Ranking indices (Bailey et al., 2006). ${ }^{24}$ Untabulated findings indicate that Pearson (Spearman) correlations range from 0.18 to $0.32(0.16$ to 0.33$)$, all of which differ significantly from zero. ${ }^{25}$ In addition, untabulated findings indicate that each of these proxies is significantly positively correlated with TRANSI and TRANSIN.

In addition, the economic intuition supporting a negative relation between TRANS and cost of capital depends on there being a negative association between TRANS and information asymmetry. Thus, we also calculate correlations between TRANS and five measures used in prior research reflecting information asymmetry: bid-ask spread (Brennan and Subrahmanyam, 1996), arbitrage risk (Mendenhall, 2004), and accrual quality and two measures related to accrual quality, the standard deviation of operating cash flows and the proportion of loss years in the prior ten years (Dechow and Dichev, 2002). We also use factor analysis to obtain a sixth information asymmetry measure based on the common variation in the individual information asymmetry measures. Untabulated findings support a negative association between TRANS and information asymmetry: Spearman (Pearson) correlations are significantly negative for all six measures, and range from $-0.20(-0.18)$ for the information asymmetry factor to $-0.08(-0.08)$ for the standard deviation of operating cash flows. ${ }^{26}$

Table 2, Panels A and B, presents summary statistics from estimating Eqs. (A2) and (A3) in Appendix A, which we use to calculate TRANS. All statistics are based on 27 annual regressions. Panel A presents results for the industry regressions used

\footnotetext{
${ }^{21}$ We set to zero fewer than $10 \%$ of the TRANSI observations. We set to zero fewer than $12 \%$, and set to 0.5 fewer than $5 \%$, of the ECC observations. Inferences from untabulated regressions in which we permit TRANSI to be negative and ECC to be negative or greater than 0.5 are identical to those from the tabulated findings.

${ }^{22}$ Throughout we use a five percent significance level under a one-sided alternative when we have a signed prediction and under a two-sided alternative otherwise.

${ }^{23}$ FFRET also reflects differences between realized and expected returns arising from new information. See Section 6.4.

24 The four indices are: (1) the S\&P Composite Ranking of ownership structure and investor rights, financial transparency and information disclosure, and board and management structure and processes; (2) the financial transparency and information disclosure sub-ranking; (3) the S\&P Composite Ranking; and (4) the financial transparency and information disclosure sub-ranking. (1) and (2) are based on information in annual reports, 10-Ks, and proxy statements; (3) and (4) are based on information in annual reports.

${ }^{25}$ Sample sizes used to compute the correlations are limited because of the availability of these alternative proxies. For the AIMR correlations, there are 3,694 firm-year observations. We have 367 firms with S\&P indices, which do not vary by year. Therefore, to correlate the S\&P indices with TRANS, we compute the average TRANS for the 367 firms with S\&P indices and correlate that average with the S\&P index.

${ }^{26}$ Because TRANS and cost of capital reflect a common set of economic fundamentals, we also correlate the information asymmetry measures with residuals from a regression of TRANS on the fundamentals we control for in Eqs. (2), (3), and (4)-leverage, size, the equity book-to-market ratio, beta, and momentum-and residuals from a regression of TRANS on these fundamentals plus analysts' growth forecasts that we control for in Section 6.4 .2 . Untabulated findings reveal significant negative associations between these two residual TRANS measures and all the information asymmetry measures.
} 
Table 1

Descriptive statistics.

Panel A: based on observations pooled across years and industries $(\mathrm{N}=51,612)$

\begin{tabular}{|c|c|c|c|c|c|}
\hline & Mean & Median & Std. & Max & Min \\
\hline TRANS & 0.42 & 0.41 & 0.18 & 1.43 & 0.03 \\
\hline TRANSI & 0.11 & 0.10 & 0.09 & 0.88 & 0.00 \\
\hline TRANSIN & 0.31 & 0.31 & 0.14 & 0.63 & 0.03 \\
\hline FFRET & 0.02 & -0.03 & 0.41 & 14.54 & -0.92 \\
\hline RET & 0.19 & 0.13 & 0.49 & 13.43 & -0.94 \\
\hline$E_{t} / P_{t-1}$ & 0.09 & 0.09 & 0.14 & 1.50 & -1.48 \\
\hline$\Delta E_{t} / P_{t-1}$ & 0.01 & 0.01 & 0.14 & 1.49 & -1.43 \\
\hline DBTA & 0.18 & 0.16 & 0.16 & 0.97 & 0.00 \\
\hline ECC & 0.16 & 0.15 & 0.12 & 0.50 & 0.00 \\
\hline
\end{tabular}

Panel B: across-year means and standard deviations within each industry

\begin{tabular}{|c|c|c|c|c|c|c|c|c|c|c|c|c|c|}
\hline & \multicolumn{2}{|c|}{ TRANS } & \multicolumn{2}{|c|}{ TRANSI } & \multicolumn{2}{|c|}{ TRANSIN } & \multicolumn{2}{|c|}{ FFRET } & \multicolumn{2}{|c|}{$D B T A$} & \multicolumn{2}{|c|}{$E C C$} & \multirow[b]{2}{*}{ Nobs } \\
\hline & Mean & Std. & Mean & Std. & Mean & Std. & Mean & Std. & Mean & Std. & Mean & Std. & \\
\hline Chemicals & 0.48 & 0.21 & 0.16 & 0.15 & 0.32 & 0.141 & 0.00 & 0.32 & 0.18 & 0.12 & 0.15 & 0.11 & 1,697 \\
\hline Computers & 0.38 & 0.18 & 0.09 & 0.08 & 0.29 & 0.138 & 0.09 & 0.63 & 0.12 & 0.13 & 0.16 & 0.14 & 3,471 \\
\hline Durable manufacturers & 0.42 & 0.17 & 0.11 & 0.05 & 0.32 & 0.140 & 0.00 & 0.40 & 0.16 & 0.13 & 0.16 & 0.13 & 13,518 \\
\hline Extractive industries & 0.41 & 0.17 & 0.10 & 0.08 & 0.32 & 0.140 & 0.00 & 0.37 & 0.23 & 0.16 & 0.16 & 0.11 & 2,111 \\
\hline Financial institutions & 0.40 & 0.17 & 0.11 & 0.07 & 0.29 & 0.133 & 0.03 & 0.27 & 0.07 & 0.10 & 0.18 & 0.10 & 6,826 \\
\hline Food & 0.49 & 0.23 & 0.17 & 0.17 & 0.32 & 0.140 & 0.06 & 0.45 & 0.19 & 0.14 & 0.14 & 0.10 & 1,633 \\
\hline Insurance, real estate & 0.38 & 0.19 & 0.09 & 0.11 & 0.29 & 0.138 & 0.01 & 0.35 & 0.35 & 0.23 & 0.17 & 0.12 & 1,374 \\
\hline Mining, construction & 0.43 & 0.20 & 0.11 & 0.11 & 0.31 & 0.141 & -0.03 & 0.42 & 0.20 & 0.16 & 0.18 & 0.13 & 1,255 \\
\hline Pharmaceuticals & 0.38 & 0.21 & 0.09 & 0.13 & 0.29 & 0.142 & 0.19 & 1.03 & 0.13 & 0.14 & 0.14 & 0.11 & 1,050 \\
\hline Retail & 0.42 & 0.17 & 0.11 & 0.06 & 0.31 & 0.138 & 0.02 & 0.41 & 0.20 & 0.14 & 0.16 & 0.12 & 5,179 \\
\hline services & 0.40 & 0.16 & 0.09 & 0.07 & 0.31 & 0.137 & 0.04 & 0.45 & 0.22 & 0.20 & 0.17 & 0.13 & 2,790 \\
\hline Textiles, printing, publishing & 0.46 & 0.18 & 0.14 & 0.08 & 0.32 & 0.138 & -0.01 & 0.32 & 0.19 & 0.14 & 0.17 & 0.12 & 4,169 \\
\hline Transportation & 0.40 & 0.18 & 0.09 & 0.08 & 0.32 & 0.141 & 0.01 & 0.33 & 0.27 & 0.17 & 0.17 & 0.11 & 2,166 \\
\hline Utilities & 0.43 & 0.19 & 0.11 & 0.09 & 0.32 & 0.137 & 0.01 & 0.20 & 0.33 & 0.09 & 0.14 & 0.07 & 4,239 \\
\hline Other & 0.62 & 0.31 & 0.32 & 0.27 & 0.30 & 0.140 & 0.01 & 0.31 & 0.19 & 0.13 & 0.19 & 0.11 & 134 \\
\hline Total nobs & & & & & & & & & & & & & 51,612 \\
\hline
\end{tabular}

Panel C: correlations, pooling observations across years and industries. Pearson (Spearman) correlations below (above) diagonal.

\begin{tabular}{|c|c|c|c|c|c|c|}
\hline & TRANS & TRANSI & TRANSIN & FFRET & $D B T A$ & ECC \\
\hline TRANS & 1.000 & 0.624 & 0.902 & 0.006 & 0.037 & -0.110 \\
\hline TRANSI & 0.673 & 1.000 & 0.276 & 0.015 & 0.003 & -0.043 \\
\hline TRANSIN & 0.888 & 0.257 & 1.000 & 0.002 & 0.038 & -0.108 \\
\hline FFRET & -0.038 & -0.022 & -0.036 & 1.000 & -0.057 & -0.042 \\
\hline$D B T A$ & 0.018 & 0.002 & 0.023 & -0.059 & 1.000 & 0.027 \\
\hline ECC & -0.121 & -0.059 & -0.121 & -0.038 & 0.026 & 1.000 \\
\hline
\end{tabular}

TRANS, earnings transparency, is the sum of the industry component, TRANSI, and the industry-neutral component, TRANSIN. TRANSI (TRANSIN) is the adjusted $R^{2}$ from annual regressions of returns, $R E T$, for year $t$ on earnings before discontinued operations and extraordinary items, deflated by lagged price, $E_{t} / P_{t-1}$, and change in earnings, deflated by lagged price, $\Delta E_{t} / P_{t-1}$, by industry as listed in Panel B (by portfolio based on the quartile of the residual from the industry regressions). FFRET is an annualized excess return computed using compounded monthly returns. Excess return is the firm's raw return in excess of the risk-free rate minus the firm's predicted return based on the Fama-French and momentum factor-mimicking portfolios, i.e., excess market return, size, book-to-market, and momentum. All returns begin three months subsequent to the firm's fiscal year end. ECC is expected cost of capital estimated based on the Fama-French and momentum factors. DBTA is the ratio of long-term debt to total assets. All correlations in Panel C are significantly different from zero, except for the Spearman correlation between TRANS and its components and FFRET. Sample of US firms, $1974-2000$.

to calculate TRANSI and Panel B presents results for the portfolio regressions used to calculate TRANSIN. Table 2, Panel A, reveals that, on average, the $R^{2}$ from the industry regressions, which is TRANSI, is at least $9 \%$, and is somewhat higher than that found in prior research (e.g., Easton and Harris, 1991). ${ }^{27}$ There is considerable cross-industry variation and cross-year variation within each industry. The coefficients on earnings and change in earnings, $E / P$ and $\triangle E / P$, also exhibit considerable cross-industry variation and cross-year variation within each industry. However, the $E / P(\Delta E / P)$ coefficient mean $t$-statistics indicate that it is significantly positive for 6 (6) industries.

Table 2, Panel B, reveals that mean $R^{2}$ from the portfolio regressions, which is mean TRANSIN, is substantially higher than mean $R^{2}$ from the industry regressions and those in prior research. TRANSIN ranges from $17 \%$ to $42 \%$. This range

\footnotetext{
27 The sample size in Table 2, Panels A and B, exceeds that of Table 1, Panel A, because we estimate Eqs. (A2) and (A3) with all available firm-year observations. Construction of FFRET and missing data result in a smaller sample size for Eqs. (2) and (4).
} 
Table 2

Summary statistics from regressions of annual returns on earnings and change in earnings. Means and standard deviations are across years.

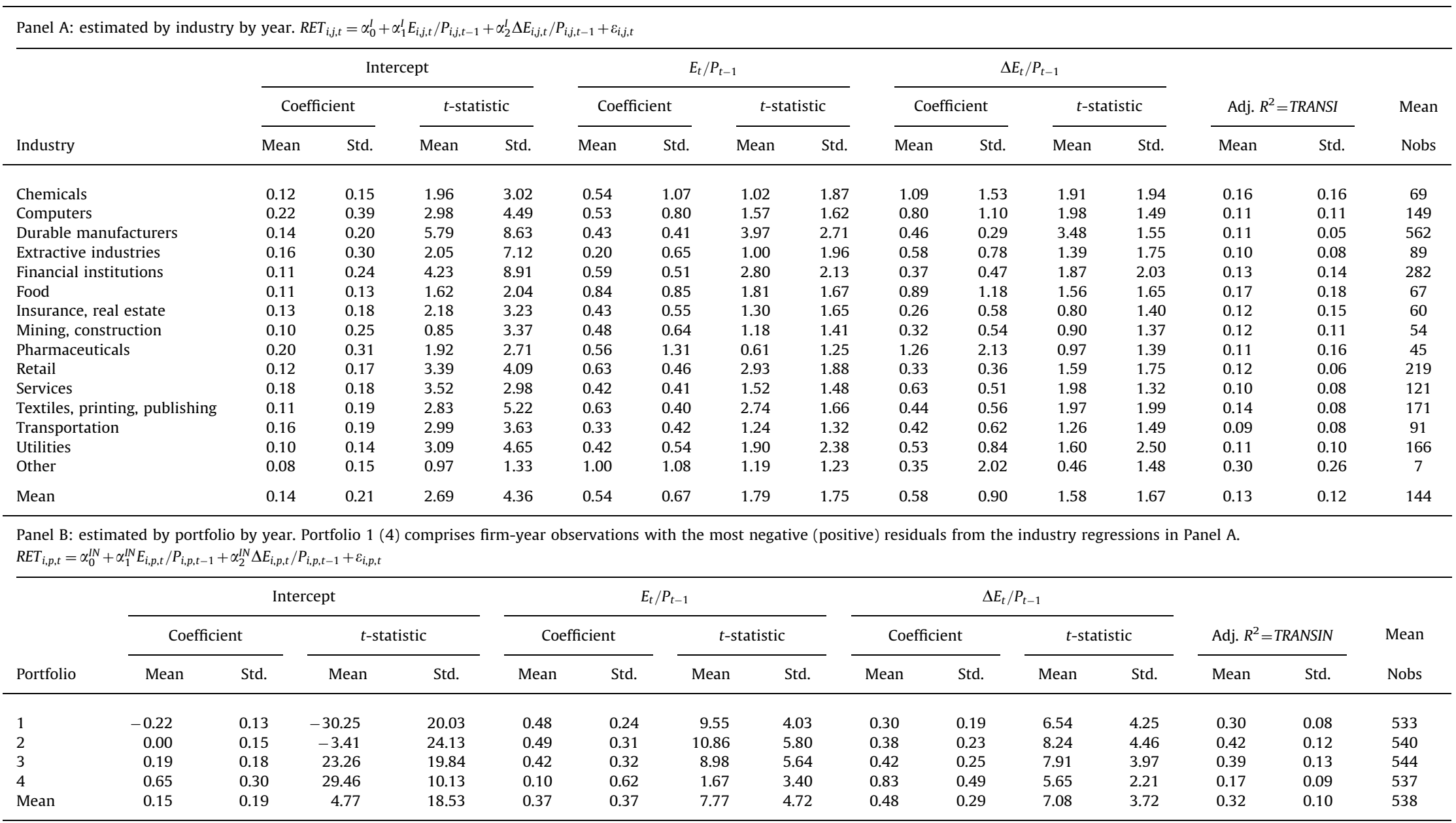

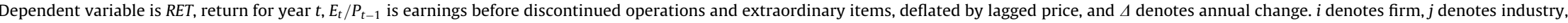
and $p$ denotes portfolio. Sample is described in Table 1. 
reflects substantial cross-portfolio variation. This high variation in TRANSIN and hence TRANS is important because it helps to increase the power of our tests. The higher $R^{2}$ s reflect the higher $t$-statistics for the $E / P$ and $\Delta E / P$ coefficients relative to those obtained from the industry regressions. These findings indicate that grouping firms into portfolios based on the industry returns-earnings regression residuals successfully identifies firms with common returns-earnings relations.

Panels A and B also reveal how the industry and industry-neutral earnings and change in earnings coefficients differ. For example, for chemical firms, the mean coefficients on earnings and change in earnings, $\alpha_{1}^{I}$ and $\alpha_{2}^{I}$, are 0.54 and 1.09 . Regardless of industry, firms in portfolio 1 have mean earnings and change in earnings coefficients, $\alpha_{1}^{I N}$ and $\alpha_{2}^{I N}$, of 0.48 and 0.30 . The analogous coefficients for firms in portfolio 4 are 0.10 and 0.83 . This illustrates that assuming all chemical firms have coefficients of 0.54 and 1.09 imposes a binding constraint, and therefore does not fully reflect the explanatory power of earnings and change in earnings for returns.

\section{Results}

\subsection{Subsequent excess and portfolio mean returns}

Table 3 presents summary statistics from estimating Eq. (2). The first column contains statistics based on pooling observations across industries and over time, and the next three columns contain statistics from by-year estimations. Table 3 reveals, as predicted, a significant negative relation between TRANS and subsequent excess returns. This finding indicates that earnings transparency is negatively associated with cost of capital. ${ }^{28}$ The TRANS $t$-statistic from the pooled regression is -2.73 , and the Fama-MacBeth $t$-statistic from the by-year estimations is -1.96 . The TRANS coefficient is -0.04 for the pooled regression, and -0.05 on average across years. Evaluated at the mean of TRANS, 0.42 , these findings are consistent with a cost of capital that is $1.7 \%$ and $2.1 \%$ lower than for a firm with TRANS equal to zero. The coefficient on leverage, DBTA, is significantly negative in both specifications. ${ }^{29}$

Table 4 presents findings from estimating Eq. (3) for each of the ten TRANS portfolios. Consistent with our predictions, the Fama-French alpha declines from 0.0065 in portfolio 1 to 0.0000 in portfolio 10 . In addition, untabulated findings from a trend regression indicate that this decline is significant $(t$-statistic $=-1.95)$. Consistent with this trend, as the final column indicates, the difference in alphas for portfolios 10 and $1,-0.0065$, is significantly negative $\left(\chi^{2}\right.$-statistic $\left.=9.96\right)$. These findings indicate that firms with higher TRANS have lower Fama-French alphas and provide additional evidence that earnings transparency is negatively associated with cost of capital.

Table 4 also indicates that the RMRF, SMB, and MOM (HML) coefficients decrease (increase) from portfolio 1 to portfolio 10. For $R M R F$, the coefficient difference between portfolios 10 and $1,-0.0423$, is insignificantly different from zero $\left(\chi^{2}\right.$-statistic $\left.=0.77\right)$. The corresponding difference for $M O M,-0.2000$, is significantly negative $\left(\chi^{2}\right.$-statistic $\left.=17.57\right)$. The decrease in the $R M R F$ and MOM coefficients is consistent with predictions in Lambert et al. (2007). The related differences in $H M L$ and SMB coefficients between portfolios 10 and $1,0.2574$ and -0.1621 , are significantly positive and negative $\left(\chi^{2}\right.$-statistics $=13.13$ and 6.92). These findings indicate that the Fama-French and momentum factors and earnings transparency reflect some common information about cost of capital. In particular, the Table 4 findings reveal that earnings transparency is negatively related to the SMB and MOM factors, and positively related to the $H M L$ factor. However, finding that the alphas vary across earnings transparency portfolios indicates that earnings transparency captures dimensions of cost of capital that the Fama-French and momentum factors do not. ${ }^{30}$

\subsection{Expected cost of capital}

Table 5 presents summary statistics analogous to those in Table 3, but relating to Eq. (4). The first (second) set of columns presents findings excluding (including) the fundamental risk characteristics. Regarding the specification that excludes the fundamental risk characteristics, Table 5 reveals, as predicted, a significant negative relation between earnings transparency, TRANS, and expected cost of capital, ECC. The TRANS $t$-statistic from the pooled regression is -2.18 ,

\footnotetext{
${ }^{28}$ Finding a negative relation between TRANS and FFRET could be attributable to periods of greater correspondence between prices and earnings being associated with lower cost of capital. That is, a negative relation could result from a temporal effect unrelated to earnings transparency. If this is the case, then one would observe a negative correlation between annual averages of TRANS and annual averages of FFRET as well as expected cost of capital, ECC. Untabulated findings based on annual means and medians reveal none of these correlations is significant.

29 To assess whether the significance of TRANS is attributable to its industry component, industry-neutral component, or both, we also estimate Eq. (2) including TRANSI and TRANSIN in place of TRANS. Untabulated findings reveal that TRANSIN is negatively related to subsequent excess returns in both estimations, but not significantly so, and that TRANSI is significantly negatively related to subsequent excess returns in both the pooled and by-year estimations.

${ }^{30}$ Our findings indicate that earnings transparency is significantly negatively associated with subsequent returns, and therefore significantly negatively associated with cost of capital. These findings do not address whether earnings transparency is a priced risk factor. Untabulated findings from implementing a Fama and MacBeth (1973) approach fail to support an inference that earnings transparency is a priced risk factor. However, this finding is not surprising in light of prior research that implements similar tests and fails to support inferences that CAPM market beta, size, and momentum are priced risk factors (Jegadeesh and Titman, 1993; Jagannathan and Wang, 1996; Lettau and Ludvigson, 2001; Fama and French, 2002; Cochran, 2005; Petkova, 2006; Core et al., 2008).
} 
Table 3

Summary statistics from regression of subsequent returns on earnings transparency and control variables.

\begin{tabular}{|c|c|c|c|c|c|}
\hline & \multirow[b]{2}{*}{ Pred } & \multirow[b]{2}{*}{ Pooled } & \multicolumn{3}{|c|}{ By year } \\
\hline & & & Mean & Std. & FM- $t$ \\
\hline Intercept & ? & 0.17 & 0.06 & 0.08 & \\
\hline$t$-statistic & & 13.55 & 1.70 & 2.44 & 3.52 \\
\hline TRANS & - & -0.04 & -0.05 & 0.12 & \\
\hline$t$-statistic & & -2.73 & -0.41 & 1.79 & -1.96 \\
\hline DBTA & ? & -0.15 & -0.14 & 0.12 & \\
\hline$t$-statistic & & -12.41 & -2.47 & 2.02 & -6.17 \\
\hline Adj. $R^{2}$ & & 0.02 & 0.01 & 0.01 & \\
\hline Nobs & & 51,612 & 1,912 & & \\
\hline
\end{tabular}

FFRET is an annualized excess return computed using compounded monthly returns. Excess return is the firm's raw return in excess of the risk-free rate less the firm's predicted return based on the Fama-French and momentum factor-mimicking portfolios, i.e., excess market return, size, book-to-market, and momentum. All returns begin three months subsequent to the firm's fiscal year end. TRANS, earnings transparency, is the sum of the industry component, TRANSI, and the industry-neutral component, TRANSIN. TRANSI (TRANSIN) is the adjusted $R^{2}$ from annual regressions of returns for year $t$ on earnings before discontinued operations and extraordinary items, deflated by lagged price, $E_{t} / P_{t-1}$, and change in earnings, deflated by lagged price, $\Delta E_{t} / P_{t-1}$, by industry as listed in Table 1, Panel B (by portfolio based on the quartile of the residual from the industry regressions). DBTA is the ratio of long-term debt to total assets. Statistics from the pooled estimation are based on pooling observations cross-sectionally and over time, and clustering residuals by firm and including year fixed effects. Statistics from the by-year estimations include mean coefficients and $t$-statistics, standard deviations of the coefficients and $t$-statistics, and Fama and MacBeth (1973) $t$-statistics. FM- $t$ is the Fama-MacBeth (1973) $t$-statistic, i.e., the mean coefficient across years divided by the standard deviation of the mean. Sample is described in Table 1.

\section{Table 4}

Summary statistics from portfolio regressions of monthly value-weighted portfolio excess returns on contemporaneous Fama-French and momentum factors. Portfolios are formed based on earnings transparency.

\begin{tabular}{|c|c|c|c|c|c|c|c|c|c|c|c|}
\hline \multicolumn{12}{|c|}{$R_{p, m}-R_{f, m}=\alpha_{p}+\beta_{R M R F, p}\left(R_{M, m}-R_{f, m}\right)+\beta_{S M B, p} S M B_{m}+\beta_{H M L, p} H M L_{m}+\beta_{M O M, p} M O M_{m}+\varepsilon_{p, m}$} \\
\hline \multicolumn{12}{|c|}{ Transparency portfolio (nobs=334) } \\
\hline & 1 & 2 & 3 & 4 & 5 & 6 & 7 & 8 & 9 & 10 & $10-1$ \\
\hline$\alpha_{p}$ & 0.0065 & 0.0038 & -0.0014 & -0.0031 & 0.0009 & -0.0007 & -0.0005 & -0.0010 & -0.0015 & 0.0000 & -0.0065 \\
\hline $\begin{array}{l}t \text {-statistic } \\
\chi^{2} \text {-statistic }\end{array}$ & 4.46 & 1.91 & -1.02 & -2.27 & 0.55 & -0.51 & -0.36 & -0.69 & -1.12 & 0.00 & 9.96 \\
\hline$\beta_{\text {RMRF }}$ & 1.0202 & 1.0000 & 1.0397 & 1.0023 & 1.0403 & 0.9973 & 1.0469 & 0.9534 & 1.0094 & 0.9779 & -0.0423 \\
\hline $\begin{array}{l}t \text {-statistic } \\
\chi^{2} \text {-statistic }\end{array}$ & 29.96 & 21.56 & 32.04 & 32.01 & 27.63 & 30.31 & 31.57 & 28.48 & 32.34 & 27.21 & 0.77 \\
\hline$\beta_{S M B}$ & -0.0254 & 0.0155 & 0.0481 & -0.0497 & -0.0366 & -0.2428 & -0.0467 & -0.1240 & 0.0107 & -0.1875 & -0.1621 \\
\hline $\begin{array}{l}t \text {-statistic } \\
\chi^{2} \text {-statistic }\end{array}$ & -0.58 & 0.26 & 1.16 & -1.24 & -0.76 & -5.77 & -1.10 & -2.90 & 0.27 & -4.08 & 6.92 \\
\hline$\beta_{H M L}$ & 0.0013 & -0.0273 & 0.0697 & 0.1787 & -0.0997 & 0.1228 & 0.4114 & 0.1284 & 0.3879 & 0.2587 & 0.2574 \\
\hline $\begin{array}{l}t \text {-statistic } \\
\chi^{2} \text {-statistic }\end{array}$ & 0.03 & -0.40 & 1.46 & 3.87 & -1.80 & 2.53 & 8.41 & 2.60 & 8.43 & 4.88 & 13.13 \\
\hline$\beta_{\text {MOM }}$ & 0.1277 & 0.2325 & 0.0170 & -0.1990 & -0.0443 & -0.0671 & -0.1109 & -0.1840 & -0.0931 & -0.0722 & -0.2000 \\
\hline $\begin{array}{l}t \text {-statistic } \\
\chi^{2} \text {-statistic }\end{array}$ & 3.79 & 5.06 & 0.53 & -6.42 & -1.19 & -2.06 & -3.38 & -5.55 & -3.01 & -2.03 & 17.57 \\
\hline Adj. $R^{2}$ & 0.78 & 0.66 & 0.80 & 0.78 & 0.76 & 0.76 & 0.76 & 0.74 & 0.77 & 0.71 & \\
\hline
\end{tabular}

In each month, $m$, we form ten portfolios based on TRANS; firms with the highest (lowest) TRANS are in portfolio ten (one). For each portfolio, using seemingly unrelated regression (Zellner, 1962), we regress the value-weighted monthly portfolio excess returns, $R_{p, m}-R_{f, m}$, on the three Fama-French factors, $\left(R_{M, m}-R_{f, m}\right), S M B_{m}$, and $H M L_{m}$, and the momentum factor, $M O M_{m}$. Portfolio value weights are based on equity market value at the beginning of month $m$. TRANS, earnings transparency, is the sum of the industry component, TRANSI, and the industry-neutral component, TRANSIN. TRANSI (TRANSIN) is the adjusted $R^{2}$ from annual regressions of returns for year $t$ on earnings before discontinued operations and extraordinary items, deflated by lagged price, $E_{t} / P_{t-1}$, and change in earnings, deflated by lagged price, $\Delta E_{t} / P_{t-1}$, by industry as listed in Table 1 , Panel $\mathrm{B}$ (by portfolio based on the quartile of the residual from the industry regressions). Sample is described in Table 1.

and its Fama-MacBeth $t$-statistic is -3.04 for the by-year estimations. The TRANS coefficient equals -0.08 in the pooled regression and -0.03 on average across years. Evaluated at the mean of TRANS in Table 1, Panel A, 0.42, and using the pooled (average across years) coefficient, these findings are consistent with an expected cost of capital that is $3.36 \%$ 
Table 5

Summary statistics from regressions of expected cost of capital on earnings transparency.

\begin{tabular}{|c|c|c|c|c|c|c|c|c|c|}
\hline & \multirow[b]{2}{*}{ Pred } & \multirow[b]{2}{*}{ Pooled } & \multicolumn{3}{|c|}{ By year } & \multirow[b]{2}{*}{ Pooled } & \multicolumn{3}{|c|}{ By year } \\
\hline & & & Mean & Std. & FM- $t$ & & Mean & Std. & FM- $t$ \\
\hline Intercept & $?$ & 0.19 & 0.17 & 0.09 & & 0.15 & 0.13 & 0.17 & \\
\hline t-statistic & & 11.35 & 21.34 & 8.93 & 9.59 & 4.79 & 10.77 & 12.09 & 4.15 \\
\hline TRANS & - & -0.08 & -0.03 & 0.06 & & -0.07 & -0.01 & 0.05 & \\
\hline t-statistic & & -2.18 & -1.45 & 3.10 & -3.04 & -2.06 & -0.77 & 2.87 & -1.68 \\
\hline$D B T A$ & $?$ & 0.02 & 0.03 & 0.03 & & 0.02 & 0.02 & 0.03 & \\
\hline t-statistic & & 1.67 & 2.10 & 2.44 & 4.33 & 2.05 & 2.05 & 2.84 & 4.02 \\
\hline MVE & - & & & & & -0.01 & -0.01 & 0.02 & \\
\hline$t$-statistic & & & & & & -1.69 & -3.45 & 14.31 & -2.09 \\
\hline$B M$ & - & & & & & -0.00 & -0.00 & 0.01 & \\
\hline t-statistic & & & & & & -0.17 & -0.12 & 4.02 & -0.18 \\
\hline Beta & + & & & & & 0.07 & 0.06 & 0.04 & \\
\hline t-statistic & & & & & & 8.70 & 16.50 & 11.10 & 8.59 \\
\hline FFMom & + & & & & & 0.03 & 0.03 & 0.03 & \\
\hline t-statistic & & & & & & 2.20 & 4.48 & 4.74 & 5.22 \\
\hline Adj. $R^{2}$ & & 0.02 & 0.01 & 0.01 & & 0.12 & 0.26 & 0.11 & \\
\hline Nobs & & 51,612 & 1,912 & & & 51,612 & 1,912 & & \\
\hline
\end{tabular}

$E C C$ is expected equity cost of capital for year $t+1$ estimated using the Fama-French and momentum factors, based on information available at the end of year $t$. TRANS, earnings transparency, is the sum of the industry component, TRANSI, and the industry-neutral component, TRANSIN. TRANSI (TRANSIN) is the adjusted $R^{2}$ from annual regressions of returns for year $t$ on earnings before discontinued operations and extraordinary items, deflated by lagged price, $E_{t} / P_{t-1}$, and change in earnings, deflated by lagged price, $\Delta E_{t} / P_{t-1}$, by industry as listed in Table 1 , Panel B (by portfolio based on the quartile of the residual from the industry regressions). $D B T A$ is the ratio of long-term debt to total assets. MVE is the natural logarithm of market value of equity, $B M$ is the equity book-to-market ratio, Beta is the CAPM beta, and FFMom is return momentum, i.e., following Fama and French, return over the ten months that end two months prior to fiscal year-end. Statistics from the pooled estimation are based on pooling observations cross-sectionally and over time, and clustering residuals by firm and year. Statistics from the by-year estimations include mean coefficients and $t$-statistics, standard deviations of the coefficients and $t$-statistics, and Fama and MacBeth (1973) $t$-statistics. FM- $t$ is the Fama-MacBeth (1973) $t$-statistic, i.e., the mean coefficient across years divided by the standard deviation of the mean. Sample is described in Table 1.

(1.26\%) lower than for a firm with TRANS equal to zero. The findings also reveal that the coefficient on DBTA is significantly positive in the pooled and by-year estimations. ${ }^{31,32}$

Regarding the specification that includes the fundamental risk characteristics, findings from the pooled and by-year Fama-MacBeth estimations reveal that three of the four coefficients on the fundamental risk variables are significantly different from zero with predicted signs. More importantly, the findings reveal that the coefficient on TRANS is significantly negative ( $t$-statistics $=-2.06$ and -1.68 in the pooled and Fama-MacBeth estimations). The lower significance level for the TRANS coefficient when fundamental risk characteristics are included in the estimating equation suggests that TRANS is correlated with them. Thus, consistent with the findings in Table 4 relating to the portfolio betas, these findings indicate that the fundamental risk characteristics and earnings transparency reflect some common information about cost of capital. However, finding that the TRANS coefficient is significantly negative when the risk characteristics are included in the estimating equation indicates that TRANS reflects information associated with ECC incremental to that reflected in these characteristics.

\subsection{Francis et al. (2004)}

Using a value relevance measure that bears some resemblance to our earnings transparency measure, Francis et al. (2004) reports evidence of a negative relation between that study's relevance measure and subsequent returns incremental to the three Fama-French factors, and a proxy for expected cost of capital. ${ }^{33}$ However, as we establish below, had Francis et al. (2004) reported correctly calculated test statistics, those statistics would have revealed an insignificant relation between that study's relevance measure and cost of capital.

\footnotetext{
${ }^{31}$ The $R^{2} \mathrm{~s}$ in the first specification in Table 5 appear low relative to those in prior research, e.g., Francis et al. (2004). However, the specification includes only TRANS and DBTA; ECC comprises the Fama-French and momentum factors, weighted by their betas. Thus, the $R^{2}$ only reflects the incremental effect associated with the two explanatory variables. Typically, prior research, e.g., Francis et al. (2004), includes the factors as additional explanatory variables, thereby increasing the $R^{2}$, as does the other specification in Table 5 . This same observation applies to Tables 3 and 4 .

32 To assess whether the significance of TRANS is attributable to its industry component, industry-neutral component, or both, we estimate Eq. (4) including TRANSI and TRANSIN in place of TRANS. Untabulated findings reveal TRANSIN (TRANSI) is significantly negatively (insignificantly) related to ECC in both estimations.

${ }^{33}$ We apply our sign convention when discussing the Francis et al. (2004) findings (see footnote 5).
} 
The Francis et al. (2004) relevance measure is the adjusted $R^{2}$ from firm-by-firm time-series returns-earnings regressions using ten-year rolling windows. Francis et al. (2004) uses its relevance measure and a factor return constructed from the measure to test for an association between relevance and cost of capital. Using subsequent returns as a measure of cost of capital, Francis et al. (2004) forms factor-mimicking portfolios based on its relevance measure to obtain factor returns for inclusion as an additional factor in firm-by-firm time-series regressions of returns on the three Fama-French factors, and estimates each firm's return sensitivity to the three Fama-French and the relevance factor returns. Using expected cost of capital implied by a model that incorporates analysts' earnings forecasts, Francis et al. (2004) estimates annual cross-sectional regressions of expected cost of capital on its relevance measure.

Francis et al. (2004) bases its inference from its subsequent returns tests on aggregated statistics from time-series regressions, and assesses significance of the relevance factor by implementing the Fama and MacBeth (1973) aggregation procedure to the time-series regression estimates. When aggregating estimates in the subsequent return tests, Francis et al. (2004) fails to adjust the resulting test statistics for cross-sectional correlation of residuals that results from the firmspecific coefficient estimates being based on observations from overlapping time periods (Schipper and Thompson, 1983). Francis et al. (2004) bases its inference from its expected cost of capital tests on aggregated statistics from year-by-year cross-sectional regressions, and assesses significance of the relevance measure by implementing the Fama and MacBeth (1973) aggregation procedure to the regression estimates. When aggregating estimates in the expected cost of capital tests, Francis et al. (2004) fails to adjust the resulting test statistics for intertemporal correlation of residuals.

We use two approaches to establish that the inference in Francis et al. (2004) that its relevance measure is negatively related to cost of capital is unfounded. First, we implement tests relating to returns analogous to those in Francis et al. (2004), taking into account cross-sectional correlation of residuals. We test whether returns on a factor-mimicking portfolio based on the Francis et al. (2004) relevance factor are significantly positively related to returns incremental to the Fama-French factors in portfolioand firm-level tests. Untabulated findings from both tests reveal that the Francis et al. (2004) relevance factor return beta is insignificant. The adjusted Fama and MacBeth (1973) $t$-statistics corresponding to the portfolio- and firm-level tests are -0.75 and $0.500^{34}$ These findings indicate that after controlling for cross-sectional correlation of residuals, the Francis et al. (2004) relevance factor return is not significantly associated with returns incremental to the three Fama-French factors. ${ }^{35}$ We also test whether the Francis et al. (2004) relevance measure is significantly negatively related to that study's expected cost of capital proxy. Untabulated findings reveal that it is not $(t$-statistic $=0.77)$.

Second, we implement our tests to determine whether the Francis et al. (2004) relevance measure is significantly negatively related to subsequent excess and portfolio mean returns, and expected cost of capital. Untabulated findings relating to Eq. (2) indicate that the relevance measure is not significantly negatively related to subsequent excess returns. The pooled regression $t-$ statistic is 0.68 , and the Fama-MacBeth $t$-statistic from the year-by-year estimations is -0.13 . Untabulated findings relating to Eq. (3) indicate that the alphas for portfolios 1 and 10 are insignificantly different $\left(\chi^{2}\right.$-statistic $\left.=0.89\right)$. Untabulated findings relating to Eq. (4) indicate that the Francis et al. (2004) relevance measure is not significantly negatively related to our measure of expected cost of capital ( $t$-statistics $=0.55$ and 0.84 in the pooled and year-by-year estimations).

The apparent similarity between the Francis et al. (2004) relevance measure and our earnings transparency measure raises the question of why there is a significant negative relation between cost of capital and our earnings transparency measure but not the Francis et al. (2004) measure. To begin, the apparent similarity is false. Untabulated Pearson and Spearman correlations between the Francis et al. (2004) relevance measure and TRANS are both -0.02 , and insignificantly different from zero. This lack of correlation is not surprising because the Francis et al. (2004) relevance measure is based on ten years of past data. As a result, the measure reflects dated information and exhibits essentially no intertemporal variation. In contrast, we construct TRANS using current data and permit it to vary intertemporally.

\subsection{Alternative specifications}

We consider alternative specifications of Eqs. (2) and (4) to assess the robustness of our inferences about the relation between earnings transparency and subsequent excess returns and expected cost of capital. Findings from these alternative specifications do not alter the inferences we draw from our primary findings.

\subsubsection{New information in subsequent returns}

Subsequent excess returns can differ from expected returns because of new information or if the four-factor model does not fully control for expected return. As a result, subsequent excess returns tests can lack power and can be biased if the

\footnotetext{
${ }^{34}$ Inferences from both the portfolio- and firm-level tests regarding significance of the Francis et al. (2004) relevance factor are unaffected by including a momentum factor return.

${ }^{35}$ Ecker et al. (2006) extends Francis et al. (2004) by showing that the loadings on a factor return based on a measure of accruals quality are correlated with proxies for earnings quality, including the Francis et al. (2004) relevance measure. This raises the possibility that accruals quality and transparency could be correlated and, therefore, reflect similar information insofar as explaining cross-sectional variation in returns. However, untabulated findings reveal that the Pearson (Spearman) correlation between TRANS and the Ecker et al. (2006) accruals quality measure is significant and negative, $-0.15(-0.16)$. In addition, untabulated findings from estimating the portfolio- and firm-level regressions of excess returns on the returns to the Fama-French factors and the Ecker et al. (2006) accruals quality factor, using the same estimation approach as described above relating to Francis et al. (2004), reveal that the accruals quality factor return is insignificantly associated with returns incremental to the Fama-French factor returns. The adjusted Fama and MacBeth (1973) $t$-statistics corresponding to the portfolio- and firm-level tests are 0.16 and -0.52 .
} 
new information or an omitted risk factor is correlated with TRANS (Elton, 1999; Vuolteenaho, 2002; Easton and Monahan, 2005). In particular, new information can alter investors' expectations of future cash flow. We include two measures of information about expected future cash flow as additional variables in our subsequent excess returns tests: change in operating cash flow (Minton and Schrand, 1999) and an indicator variable for whether earnings is negative. Change in operating cash flow, $\triangle C F O$, is the difference between year $t+1$ and year $t$ operating cash flow, CFO, deflated by total assets at the end of year $t$, where $C F O$ is the annual equivalent to the quarterly $C F O{ }^{36}$ We set the negative earnings indicator variable, $N E G$, equal to one if earnings in year $t+1$, i.e., $E_{t+1}$, is negative and zero otherwise. Regarding a potential omitted risk factor, we include the coefficient of variation in cash flow as a control for cash flow risk (Minton and Schrand, 1999). The coefficient of variation in cash flow, CVCF, is the coefficient of variation in a firm's quarterly operating cash flow over the six-year period preceding each sample year minus the median coefficient of variation in cash flow for firms in the same two-digit SIC code.

Table 6 reports findings from specifications of Eq. (2) supplemented with combinations of each of the additional variables, NEG, $\triangle C F O$, and $C V C F$. For the sake of parsimony, we tabulate only coefficients and test statistics corresponding to TRANS. Although untabulated findings indicate that the coefficients on NEG, $\triangle C F O$, and CVCF are often significantly different from zero, the key result presented in Panel A is that in all specifications the coefficient on TRANS is significantly negative in both the pooled and by-year estimations. These findings indicate that our inferences relating to TRANS from the findings in Table 3 are unaffected by inclusion of controls for new information about expected future cash flow and cash flow risk.

\subsubsection{Correlation between TRANS and growth}

Because earnings of high growth firms are more likely to omit information about changes in future revenues and expenses, high growth firms have lower earnings transparency and lower $R^{2} \mathrm{~s}$ in the returns-earnings relation, i.e., lower values of TRANS. However, this omission also results in TRANS being correlated with a firm's investment profile, which could confound our inferences that earnings transparency is related to cost of capital. To the extent that high growth firms are riskier, they will have higher costs of capital. As a result, TRANS could be negatively related to cost of capital solely because of the negative correlation between TRANS and growth. ${ }^{37}$ To the extent that the Fama-French and momentum factors reflect dimensions of growth (Lettau and Ludvigson, 2001; Petkova, 2006), Eqs. (2), (3), and (4) implicitly control for the effect of growth on cost of capital. Thus, our finding a significant relation between TRANS and cost of capital in these equations cannot be attributed to growth as reflected in these factors. However, because the Fama-French and momentum factors may not reflect fully all dimensions of growth, we also estimate Eqs. (2), (3), and (4) including analysts' long-term earnings growth forecasts as an explicit proxy for growth. Untabulated findings reveal that although the growth proxy's coefficient is significantly different from zero in some specifications, the TRANS coefficient remains significantly negative. Thus, our inferences regarding the relation between earnings transparency and cost of capital are unchanged when we include an explicit proxy for growth. ${ }^{38}$

\subsubsection{Correlation between TRANS and earnings response coefficients}

Earnings response coefficients (ERCs) are positively correlated with model explanatory power (Johnston, 1984; Collins and Kothari, 1989; Kothari, 2001). Because TRANS is the sum of $R^{2} \mathrm{~s}$ from two returns-earnings regressions, a positive correlation between ERCs and the $R^{2}$ s from our regressions is a potential confounding factor or alternative explanation for our finding a negative relation between TRANS and cost of capital. A higher ERC is consistent with a lower cost of capital (Collins and Kothari, 1989). Therefore, finding that higher TRANS is associated with lower cost of capital could be a result of a positive correlation between TRANS and ERCs. For our sample, ERCs and $R^{2} \mathrm{~s}$ are positively correlated. For example, focusing on the ERC for earnings, the correlation between ERC and $R^{2}$ from the first-stage (second-stage) regression is $0.40(0.52)$. The analogous correlation between TRANS and the ERC is $0.34(0.49)$. To mitigate the possibility that the correlation between TRANS and ERCs affects our inferences, we estimate Eqs. (2), (3), and (4) alternatively including the average of the ERCs from the two stages, and the ERC from each stage. Untabulated findings relating to all three specifications of each equation reveal our inferences regarding the relation between TRANS and cost of capital are unchanged.

\subsubsection{Implied expected cost of capital}

Our proxy for expected cost of capital used in estimation of Eq. (4) is based on the four-factor model. Use of the model assumes that the four factors reflect all dimensions of risk. Our findings in Table 3 indicate that this assumption may not

\footnotetext{
${ }^{36}$ Quarterly CFO is sales minus the sum of cost of goods sold, selling, general, and administrative expenses, and the change in working capital. Working capital is current assets other than cash and short-term investments minus current liabilities, and is calculated as the sum of accounts receivable, inventory, and other current assets minus the sum of accounts payable, income taxes payable, and other current liabilities. Quarterly selling, general, and administrative expenses exclude one-quarter of annual research and development costs and advertising expenses when those data items are available.

${ }^{37}$ Although some prior studies suggest that growth is positively related to cost of capital, others suggest it is negatively correlated (e.g., Fama and French, 1992). See Zhang (2005) for further discussion.

${ }^{38}$ It is possible that using alternative growth proxies or specifications could result in different inferences.
} 
Table 6

Summary statistics from alternative specifications of the regression of subsequent excess returns on earnings transparency.

\begin{tabular}{|c|c|c|c|c|c|c|c|c|}
\hline & \multirow[b]{2}{*}{ Pred } & \multicolumn{3}{|c|}{ Pooled } & \multicolumn{4}{|c|}{ By Year } \\
\hline & & Coef. & $R^{2}$ & Nobs & Mean Coef. & Std. & FM- $t$ & Mean $R^{2}$ \\
\hline $\begin{array}{l}\text { Model 1: TRANS } \\
t \text {-statistic }\end{array}$ & - & $\begin{array}{l}-0.04 \\
-2.83\end{array}$ & 0.04 & 51,612 & $\begin{array}{l}-0.04 \\
-0.43\end{array}$ & $\begin{array}{l}0.11 \\
1.73\end{array}$ & -2.04 & 0.04 \\
\hline $\begin{array}{l}\text { Model 2: TRANS } \\
t \text {-statistic }\end{array}$ & - & $\begin{array}{l}-0.06 \\
-3.29\end{array}$ & 0.03 & 33,875 & $\begin{array}{l}-0.05 \\
-0.54\end{array}$ & $\begin{array}{l}0.15 \\
1.56\end{array}$ & -1.80 & 0.07 \\
\hline $\begin{array}{l}\text { Model 3: TRANS } \\
t \text {-statistic }\end{array}$ & - & $\begin{array}{l}-0.07 \\
-3.53\end{array}$ & 0.02 & 33,967 & $\begin{array}{l}-0.11 \\
-0.60\end{array}$ & $\begin{array}{l}0.25 \\
1.62\end{array}$ & -2.35 & 0.02 \\
\hline $\begin{array}{l}\text { Model 4: TRANS } \\
t \text {-statistic }\end{array}$ & - & $\begin{array}{l}-0.06 \\
-3.49\end{array}$ & 0.05 & 33,875 & $\begin{array}{l}-0.05 \\
-0.57\end{array}$ & $\begin{array}{l}0.14 \\
1.43\end{array}$ & -7.70 & 0.07 \\
\hline $\begin{array}{l}\text { Model 5: TRANS } \\
\text { t-statistic }\end{array}$ & - & $\begin{array}{l}-0.07 \\
-3.71\end{array}$ & 0.04 & 33,967 & $\begin{array}{l}-0.11 \\
-0.63\end{array}$ & $\begin{array}{l}0.24 \\
1.50\end{array}$ & -7.92 & 0.06 \\
\hline $\begin{array}{l}\text { Model 6: TRANS } \\
\text { t-statistic }\end{array}$ & - & $\begin{array}{l}-0.06 \\
-3.29\end{array}$ & 0.03 & 33,875 & $\begin{array}{l}-0.09 \\
-0.53\end{array}$ & $\begin{array}{l}0.22 \\
1.56\end{array}$ & -2.24 & 0.05 \\
\hline $\begin{array}{l}\text { Model 7: TRANS } \\
\text { t-statistic }\end{array}$ & - & $\begin{array}{l}-0.06 \\
-3.49\end{array}$ & 0.05 & 33,875 & $\begin{array}{l}-0.09 \\
-0.57\end{array}$ & $\begin{array}{l}0.21 \\
1.44\end{array}$ & -2.29 & 0.08 \\
\hline
\end{tabular}

FFRET is an annualized excess return computed using compounded monthly returns. Excess return is the firm's raw return in excess of the risk-free rate less the firm's predicted return based on the Fama-French and momentum factor-mimicking portfolios, i.e., excess market return, size, book-to-market, and momentum. All returns begin three months subsequent to the firm's fiscal year end. TRANS, earnings transparency, is the sum of the industry component, TRANSI, and the industry-neutral component, TRANSIN. TRANSI (TRANSIN) is the adjusted $R^{2}$ from annual regressions of returns for year $t$ on earnings before discontinued operations and extraordinary items, deflated by lagged price, $E_{t} / P_{t-1}$, and change in earnings, deflated by lagged price, $\Delta E_{t} / P_{t-1}$, by industry as listed in Table 1, Panel B (by portfolio based on the quartile of the residual from the industry regressions). DBTA is the ratio of long-term debt to total assets. NEG is an indicator variable that equals 1 if $E_{t}$ is negative, and 0 otherwise. $\triangle O C F$ is annual change in realized operating cash flow, defined as the difference between one-year ahead and current year $O C F$, deflated by current year total assets. Current year $O C F$ is the annual equivalent to the quarterly OCF defined in Minton and Schrand (1999). CVCF is the coefficient of variation in cash flow, defined following Minton and Schrand (1999) as the coefficient of variation in a firm's quarterly operating cash flow over the six-year period preceding each sample year. Statistics from the pooled estimation are based on pooling observations cross-sectionally and over time, and clustering residuals by firm and including year fixed effects. Statistics from the by-year estimations include mean coefficients and $t$-statistics, standard deviations of the coefficients and $t$-statistics, and Fama and MacBeth (1973) $t$-statistics. FM- $t$ is the Fama-MacBeth (1973) $t$-statistic, i.e., the mean coefficient across years divided by the standard deviation of the mean. Sample is described in Table 1.

be warranted. An alternative approach is to use a measure of expected cost of capital implied by a model that incorporates analysts' earnings forecasts. Studies that adopt this approach, including Claus and Thomas (2001), Gebhardt et al. (2001), Gode and Mohanram (2003), and Easton (2004), develop somewhat different implied expected cost of capital measures. Therefore, to assess the robustness of our findings in Table 5, we estimate Eq. (4) using the mean of the several measures of implied expected cost of capital (Hail and Leuz, 2006; Dhaliwal et al., 2007; Barth et al., 2008). Also, because Gode and Mohanram (2008) and McInnis (2010) find that estimates of implied expected cost of capital reflect bias in analysts' forecasts, we use the procedure in Gode and Mohanram (2008) to correct the implied expected cost of capital measures for analysts' forecast bias. Untabulated findings reveal that TRANS is significantly negatively associated with the mean implied expected cost of capital measure, with a $t$-statistic of -2.33 . Additional untabulated findings reveal that TRANS is significantly negatively associated with each of the four component measures.

\section{Conclusion}

This study examines whether firms with more transparent earnings enjoy a lower cost of capital. We base our measure of earnings transparency on the explanatory power of the returns-earnings relation, i.e., the extent to which earnings and change in earnings covary contemporaneously with returns.

We find that earnings transparency is significantly negatively associated with cost of capital by showing that our earnings transparency measure is negatively related to subsequent excess returns and differences in portfolio mean subsequent returns incremental to the three Fama-French and momentum factors. These findings indicate that earnings transparency captures dimensions of cost of capital that the factors do not. We also find a significant negative relation between our earnings transparency measure and an estimate of expected cost of capital based on the four-factor model. 
This finding indicates that earnings transparency is systematically related to the Fama-French and momentum factors. However, we also find that earnings transparency reflects information associated with expected cost of capital incremental to that reflected in the fundamental risk characteristics underlying these factors. Inferences relating to the subsequent excess and portfolio mean returns and expected cost of capital tests are robust to inclusion of explicit controls for leverage, growth, and the magnitude of the earnings response coefficient in the returns-earnings relation. The subsequent excess and portfolio mean returns inferences are robust to including controls for changes in cash flow and cash flow risk. The expected cost of capital inferences are robust to using a measure of expected cost of capital implied by analysts' earnings forecasts. Taken together, our findings provide evidence that firms with more transparent earnings enjoy a lower cost of capital.

\section{Appendix A}

\section{A.1. Calculation of earnings transparency proxy}

Eq. (1), repeated here as Eq. (A1), expresses TRANS as the sum of two measures, TRANSI and TRANSIN:

$$
\operatorname{TRANS}_{i, t} \equiv \operatorname{TRANSI}_{j, t}+\operatorname{TRANSIN}_{p, t}
$$

To calculate TRANSI, we estimate Eq. (A2):

$$
R E T_{i, j, t}=\alpha_{0}^{I}+\alpha_{1}^{I} E_{i, j, t} / P_{i, j, t-1}+\alpha_{2}^{I} \Delta E_{i, j, t} / P_{i, j, t-1}+\varepsilon_{i, j, t}
$$

$R E T$ is annual return measured beginning three months after the firm's fiscal year end, $E_{t} / P_{t-1}$ is earnings before extraordinary items and discontinued operations deflated by beginning of year price, and $\Delta E$ is change in earnings from year $t-1$ to year $t .^{39}$ We estimate this model for 27 years $(t=1974, \ldots, 2000)$ and for 15 industries, provided there are at least 10 observations for that industry-year. This yields 396 separate industry components, TRANSI ${ }_{j, t}$. This estimation procedure constrains the coefficients in Eq. (A2), $\alpha_{0}^{I}, \alpha_{1}^{I}$, and $\alpha_{2}^{I}$, to be the same for firms within industry $j$ in year $t$.

To calculate TRANSIN, we estimate Eq. (A3):

$$
R E T_{i, p, t}=\alpha_{0}^{I N}+\alpha_{1}^{I N} E_{i, p, t} / P_{i, p, t-1}+\alpha_{2}^{I N} \Delta E_{i, p, t} / P_{i, p, t-1}+\varepsilon_{i, p, t} .
$$

When estimating Eq. (A3), we place observations from each industry-year regression, i.e., Eq. (A2), into one of four portfolios based on the magnitude of their associated residuals from each annual regression for that industry. ${ }^{40}$ We estimate Eq. (A3) by year, pooling observations in portfolio $p, p=1, \ldots, 4$. This permits the industry-neutral component of earnings transparency to vary over time. Because there are 27 years and 4 portfolios, we estimate 108 regressions,

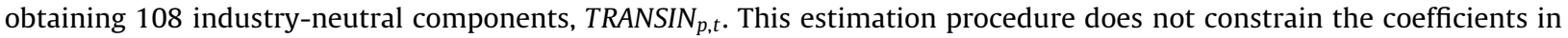
Eq. (A3), $\alpha_{0}^{I N}, \alpha_{1}^{I N}$, and $\alpha_{2}^{I N}$, to be the same for firms within industry $j$ in year $t$. Rather, it constrains firms within portfolio $p$ to have the same coefficients in year $t$.

As an illustration, consider a hypothetical industry $j$, which has 100 observations per year. For each year, we rank the 100 residuals from 1 to 100 and place into portfolio 1 the 25 observations with the largest negative residuals, place into portfolio 2 the observations with the next largest 25 residuals, and so on, until each observation is assigned to a portfolio. We repeat this procedure for all 27 years and all 15 industries, so that portfolio 1 contains the quartile of observations with the largest negative residuals from each of the 15 industries in each year, portfolio 2 contains the quartile of observations with the next largest residuals from each of the 15 industries in each year, and so on. Thus, portfolios 1 and 4 , which contain the observations with the largest negative and largest positive residuals from the annual industry regressions, comprise those firm-year observations for which the annual industry return regression model is least descriptive.

Selection of the optimal number of portfolios is an empirical matter reflecting a tradeoff between precision of estimation and forcing otherwise different groups of firms to have the same earnings transparency measure. For example, suppose instead of four portfolios we partitioned firms into eight portfolios, but firms in portfolios 1 and 2, 3 and 4, 5 and 6 , and 7 and 8 have identical earnings transparency. This would result in a loss of estimation efficiency compared with partitioning firms into four portfolios, combining portfolios 1 and 2, 3 and 4, 5 and 6, and 7 and 8 . In contrast, suppose instead eight portfolios capture differences in earnings transparency, then partitioning firms into four portfolios masks the cross-sectional earnings transparency differences. ${ }^{41}$

\footnotetext{
${ }^{39}$ Following Easton and Pae (2004), we also estimated versions of Eqs. (A2) and (A3) including year $t-1$ dividends and the effects of other comprehensive income. Untabulated findings indicate that none of our inferences is affected using this alternative specification.

40 This procedure assumes that residuals of equal magnitude are equally informative about industry-neutral commonality regardless of the firm's industry regression standard error. To the extent that this procedure results in misclassifying firms across portfolios, our tests will be biased against finding an association between TRANS and cost of capital.

${ }^{41}$ Untabulated findings indicate that the significance of the TRANS coefficient in Eq. (2) is highest when we use four portfolios, although it is also significant for other numbers of portfolios.
} 


\section{A.2.Calculation of expected cost of capital proxy}

We calculate our proxy for each firm's expected cost of capital for year $t+1$ as of year $t, E C C_{i, t}$, based on Eq. (A4):

$$
E C C_{i, t}=\bar{R}_{f, t}+\hat{\beta}_{R M R F, i, t} \times{\overline{\left(R_{M}-R_{f}\right.}}_{t}+\hat{\beta}_{S M B, i, t} \times \overline{S M B}_{t}+\hat{\beta}_{H M L, i, t} \times \overline{H M L}_{t}+\hat{\beta}_{M O M, i, t} \times \overline{M O M}_{t},
$$

where $\hat{\beta}_{R M R F, i, t}, \hat{\beta}_{S M B, i, t}, \hat{\beta}_{H M L, i, t}$, and $\hat{\beta}_{M O M, i, t}$ are firm-specific coefficients estimated from Eq. (A5). $\left.\overline{(R}_{M}-R_{f}\right)_{t}, \overline{S M B}_{t}, \overline{H M L}_{t}$, and $\overline{M O M}_{t}$ are the expected annual Fama-French and momentum factor returns for year $t+1$. We estimate the expected annual factor returns by first calculating each factor's average monthly return over the 60 months prior to month $m$, and then compounding the resulting average monthly returns over the twelve months prior to the beginning of firm $i$ 's fiscal year. ${ }^{42}$

For each firm, we estimate the betas associated with the firm's return to each of the factors by estimating the following monthly time-series regression:

$$
R E T_{i, m}-R_{f, m}=\alpha_{i}+\beta_{R M R F, i}\left(R_{M, m}-R_{f, m}\right)+\beta_{S M B, i} S M B_{m}+\beta_{H M L, i} H M L_{m}+\beta_{M O M, i} M O M_{m}+\varepsilon_{i, m},
$$

where $R E T_{m}-R_{f, m}$ is the firm's monthly return in excess of the risk-free rate, $R_{f, t} . R_{M, m}-R_{f, m}$ is the monthly return of the market portfolio in excess of the risk-free rate, $H M L_{m}$ and $S M B_{m}$ are the monthly returns to the book-to-market and size factor mimicking portfolios as described in Fama and French (1993), and $M O M_{m}$ is the monthly return to the momentum factor mimicking portfolio (Jegadeesh and Titman, 1993; Carhart, 1997). We estimate Eq. (A5) using the most recent 60 months returns prior to the beginning of firm $i$ 's fiscal year $t$. This results in estimated coefficients, $\hat{\beta}_{R M R F, i, t}, \hat{\beta}_{S M B, i, t}, \hat{\beta}_{H M L, i, t}$, and $\hat{\beta}_{M O M, i, t}$ that are updated annually.

\section{References}

Ang, A., Liu, J., 2004. How to discount cash flows with time-varying expected returns. The Journal of Finance 59, $2745-2783$.

Bailey, W., Karolyi, G.A., Salva, C., 2006. The economic consequences of increased disclosure: evidence from international cross-listings. Journal of Financial Economics 81, 175-213.

Barth, M.E., Beaver, W.H., Landsman, W.R., 1998. Relative valuation roles of equity book value and net income as a function of financial health. Journal of Accounting and Economics 25, 1-34.

Barth, M.E., Beaver, W.H., Hand, J.M., Landsman, W.R., 1999. Accruals, cash flows, and equity values. Review of Accounting Studies 4, 205-229.

Barth, M.E., Beaver, W.H., Hand, J.M., Landsman, W.R., 2005. Accruals, accounting-based valuation models, and the prediction of equity values. Journal of Accounting, Auditing, and Finance 20, 311-345.

Barth, M.E., Hodder, L.D., Stubben, Stephen R., 2008. Fair value accounting for liabilities and own credit risk. The Accounting Review 83, 629-664.

Beatty, A., Ramesh, K., Weber, J., 2002. The importance of accounting changes in debt contracts: the cost of flexibility in covenant calculations. Journal of Accounting and Economics 29, 2005-2027.

Bhattacharya, U., Daouk, H., Welker, M., 2003. The world price of earnings opacity. The Accounting Review 78, 641-678.

Botosan, C.A., 1997. Disclosure level and the cost of equity capital. The Accounting Review 72, 323-349.

Botosan, C.A., Plumlee, M., 2002. A re-examination of disclosure level and expected cost of equity capital. Journal of Accounting Research 40, 21-40.

Brennan, M.J., Subrahmanyam, A., 1996. Market microstructure and asset pricing: on the compensation for illiquidity in stock returns. Journal of Financial Economics 41, 441-464.

Bushman, R., Chen, Q., Engel, E., Smith, A., 2004. Financial accounting information, organizational complexity and corporate governance systems. Journal of Accounting and Economics 37, 167-201.

Campbell, J.Y., Lettau, M., Malkiel, B.G., Xu, Y., 2001. Have individual stocks become more volatile? An empirical exploration of idiosyncratic risk. The Journal of Finance 56, 1-43.

Carhart, M.M., 1997. On persistence in mutual fund performance. The Journal of Finance 52, 57-82.

Claus, J., Thomas, J., 2001. Equity premia as low as three percent? Evidence from analysts' earnings forecasts for domestic and international stock markets. The Journal of Finance 56, 1629-1666.

Cochran, J.H., 2005. Asset Pricing. Princeton University Press, Princeton, New Jersey.

Collins, D.W., Kothari, S., 1989. An analysis of intertemporal and cross-sectional determinants of earnings response coefficients. Journal of Accounting and Economics 11, 143-181.

Collins, D.W., Maydew, E.L., Weiss, I.S., 1997. Changes in the value-relevance of earnings and equity book values over the past forty years. Journal of Accounting and Economics 24, 39-67.

Core, J.E., Guay, W.R., Verdi, R.S., 2008. Is accruals quality a priced risk factor? Journal of Accounting and Economics $46,2-22$.

Daske, H., Hail, L., Leuz, C., Verdi, R., 2008. Mandatory IFRS reporting around the world: early evidence on the economic consequences. Journal of Accounting Research 46, 1085-1142.

Dechow, P.M., Dichev, I.D., 2002. The quality of accruals and earnings: the role of accrual estimation errors. The Accounting Review 77, 35-59.

Dhaliwal, D., Heitzman, S., Li, O.Z., 2007. Taxes, leverage, and the cost of equity capital. Journal of Accounting Research 44, 691-723.

Diamond, D.W., Verrecchia, R.E., 1991. Disclosure, liquidity, and the cost of capital. The Journal of Finance 46, 1325-1359.

Easton, P.D., 2004. PE ratios, PEG ratios, and estimating the implied expected rate of return on equity capital. The Accounting Review 79, 73-95.

Easton, P., Harris, T., 1991. Earnings as an explanatory variable for return. Journal of Accounting Research 29, 19-36.

Easton, P., Monahan, S., 2005. An evaluation of accounting-based measures of expected returns. The Accounting Review 80, 501-538.

Easton, P., Pae, J., 2004. Accounting conservatism and the relation between returns and accounting data. Review of Accounting Studies 9, 495-521.

Ecker, F., Francis, J., Kim, I., Olsson, P.M., Schipper, K., 2006. A returns-based representation of earnings quality. The Accounting Review 81, 749-780.

Elton, E., 1999. Expected return, realized return, and asset pricing tests. The Journal of Finance 54, 1199-1220.

Fama, E.F., French., K.R., 1992. The cross-section of expected stock returns. The Journal of Finance 47, 427-465.

Fama, E.F., French., K.R., 1993. Common risk factors in the returns of stocks and bonds. Journal of Financial Economics $33,3-56$.

Fama, E.F., French, K.R., 1997. Industry costs of equity. Journal of Financial Economics 43, 153-193.

Fama, E.F., French, K.R., 1998. Taxes, financing decisions, and firm value. The Journal of Finance 53, 819-843.

Fama, E.F., French., K.R., 2002. The equity premium. The Journal of Finance 57, 637-659.

Fama, E.F., MacBeth, J.D., 1973. Risk, return, and equilibrium: empirical tests. Journal of Political Economy 81, $607-636$.

42 Because five-year rolling windows may result in an outdated estimated risk-free rate, we calculate the expected monthly risk-free rate based on a one-year rolling risk-free rate, updated monthly. The expected annual risk-free rate, $\bar{R}_{f, t}$, is obtained by compounding the expected monthly risk-free rate. 
Financial Accounting Standards Board, 1998. Statement of Financial Accounting Standards No. 133: Accounting for Derivative Instruments and Hedging Activities. Norwalk, CT.

Francis, J., LaFond, R., Olsson, P., Schipper, K., 2004. Costs of equity and earnings attributes. The Accounting Review 79, $967-1010$.

Francis, J., LaFond, R., Olsson, P., Schipper, K., 2005. The market pricing of accruals quality. Journal of Accounting and Economics 39, $295-327$.

Gebhardt, W.R., Lee, C.M.C., Swaminathan, B., 2001. Toward an implied cost of capital. Journal of Accounting Research 39, 135-176.

Gode, D., Mohanram, P., 2003. Inferring the cost of equity using the Ohlson-Juettner model. Review of Accounting Studies 8, 399-431.

Gode, D., Mohanram, P., 2008. Improving the Relationship Between Implied Cost of Capital and Realized Returns by Removing Predictable Analyst Forecast Errors. Working Paper.

Gow, I.D., Ormazabal, G., Taylor, D.J., 2010. Correcting for cross-sectional and time-series dependence in accounting research. Accounting Review 85, 483-512.

Hail, L., Leuz, C., 2006. International differences in the cost of equity capital: do legal institutions and securities regulation matter? Journal of Accounting Research 44, 485-532.

Healy, P., Hutton, A., Palepu, K., 1999. Stock performance and intermediation changes surrounding sustained increases in disclosure. Contemporary Accounting Research 16, 485-520.

Hughes, J., Liu, J., Liu, J., 2007. Information, diversification, and cost of capital. The Accounting Review 82, $705-729$.

Ibbotson Associates, 2005. In: Cost of Capital 2005 Yearbook Ibbotson Associates, Inc., Chicago, Illinois.

Jagannathan, R., Wang, Z., 1996. The conditional CAPM and the cross-section of expected returns. The Journal of Finance 51, 3-53.

Jegadeesh, N., Titman, S., 1993. Returns to buying winners and selling losers: implications for stock market efficiency. The Journal of Finance 48, 65-91. Johnston, J., 1984. Econometric Methods, 3rd edition McGraw-Hill, Inc..

Konchitchki, Y., 2011. Inflation and nominal financial reporting: implications for performance and stock prices. The Accounting Review 86, 1045-1085

Kothari, S., 2001. Capital markets research in accounting. Journal of Accounting and Economics 31, $105-231$.

Kothari, S., Zimmerman, J., 1995. Price and return models. Journal of Accounting and Economics 20, $155-192$.

Kyle, A.S., 1985. Continuous auctions and insider trading. Econometrica 53, 1315-1336.

Lambert, R., Leuz, C., Verrecchia, R., 2007. Accounting information, disclosure, and the cost of capital. Journal of Accounting Research 45, 385-420.

Lang, M., Lundholm, R., 2000. Voluntary disclosure and equity offerings: reducing information uncertainty or hyping the stock. Contemporary Accounting Research 17, 623-662.

Lettau, M., Ludvigson, S., 2001. Resurrecting the (C)CAPM: a cross-sectional test when risk premia are time-varying. Journal of Political Economy 109, $1238-1287$.

Leuz, C., 2003. IAS versus U.S. GAAP: information asymmetry-based evidence from Germany's new market. Journal of Accounting Research 41, 445-472. Leuz, C., Verrecchia, R.E., 2000. The economic consequences of increased disclosure. Journal of Accounting Research 38, 91-124.

Lev, B., 1989. On the usefulness of earnings and earnings research: lessons and directions from two decades of empirical research. Journal of Accounting Research 27, 153-192.

Massa, M., Peyer, U., Tong, Z., 2005. Limits of Arbitrage and Corporate Financial Policy. Working Paper.

McInnis, J., 2010. Earnings smoothness, average returns, and implied equity cost of capital. The Accounting Review 85, $315-341$.

Mendenhall, R.R., 2004. Arbitrage risk and post-earnings-announcement drift. Journal of Business 77, 875-894.

Minton, B., Schrand, C., 1999. The impact of cash flow volatility on discretionary investment and the costs of debt and equity financing. Journal of Financial Economics 54, 423-460.

Mohanram, P., Rajgopal, S., 2009. Is PIN priced? Journal of Accounting and Economics 47, 226-243.

Ohlson, J., 1995. Earnings, book values and dividends in security valuation. Contemporary Accounting Research 11, $661-687$.

Petersen, M.A., 2009. Estimating standard errors in finance panel data sets: comparing approaches. Review of Financial Studies 22, 435-480.

Petkova, R., 2006. Do the Fama-French proxy for innovations in predictive variables? The Journal of Finance 61, 581-612.

Rouwenhorst, K.G., 1998. International momentum strategies. The Journal of Finance 53, 267-284.

Schipper, K., Thompson, R., 1983. The impact of merger-related regulations on the shareholders of acquiring firms. Journal of Accounting Research 21 184-221.

Sengupta, P., 1998. Corporate disclosure policy and the cost of debt. The Accounting Review 73, 459-474.

Vuolteenaho, T., 2002. What drives firm-level stock returns? The Journal of Finance 57, 233-264.

Welker, M., 1995. Disclosure policy, information asymmetry and liquidity in equity markets. Contemporary Accounting Research 11, 801-828.

Xu, Y., Malkiel, B.G., 2003. Investigating the behavior of idiosyncratic volatility. Journal of Business 76, 613-644.

Zhang, L., 2005. The value premium. The Journal of Finance 60, 67-103.

Zellner, A., 1962. An efficient method for estimating seemingly unrelated regressions and tests for aggregation bias. Journal of the American Statistical Association 57, 348-368. 